https://helda.helsinki.fi

\title{
On the grammaticalization of Finnish colorative construction
}

\author{
Hamunen, Markus Veli Juhani
}

2017-11-20

Hamunen, M V J 2017 , ' On the grammaticalization of Finnish colorative construction ', Constructions and Frames, vol. 9 , no. 1 , pp. 101-138 . https://doi.org/10.1075/cf.9.1.04ham

http://hdl.handle.net/10138/307280

https://doi.org/10.1075/cf.9.1.04ham

unspecified

acceptedVersion

Downloaded from Helda, University of Helsinki institutional repository.

This is an electronic reprint of the original article.

This reprint may differ from the original in pagination and typographic detail.

Please cite the original version. 


\section{On the Grammaticalization of Finnish Colorative Construction}

This paper concentrates on the diachronic development of the so-called Colorative Construction $(\mathrm{CoC})$ in Finnish, a two-verb expression consisting of an A-infinitive and an ideophonic-based descriptive (or "colorative") finite verb, e.g., susi juos-ta jolkottele-e [wolf run-INF COL-PRS.3SG] "wolf runs trotting". The paper combines variationist dialectal data, grammaticalization theory and Construction Grammar formalization. The detailed diachronic description demonstrates that development from proto-CoC to modern $\mathrm{CoC}$ is the epitome of constructionalization, i.e., a gradual process of grammatical changes whereby both the form and the function of an existing construction is altered, creating a new expression type. Major changes in the Balto-Finnic case system were the primary force behind this process. Constructionalization of the $\mathrm{CoC}$ itself included the first syntagmatic changes through reanalysis. This gradually created a new paradigmatic expression type, followed by paradigmatic extension through analogy, which widened the frame semantics of the newly coined type.

Keywords: Construction Grammar, constructionalization, infinitives, expressive verbs, corpus syntax, dialects, variation, diachronic syntax

\section{Introduction}

\subsection{Overview of the Finnish Colorative Construction}

The rich derivative suffix system of the Finnish allows a strong tendency to lexicalize multiple ideophonic roots (see Erhard Voeltz \& Kilian-Hatz 2001: 1-8) as verbs or nouns. Particularly in dialectal speech, there are countless verbs that denote, for example, the manner of running: hampsii "s/he runs with haste", jolkottaa "s/he runs jogging without haste", kaahottaa "s/he runs fussing", lipottelee "s/he runs lightly with small steps", paarustaa "s/he runs in a burdersome way", pinkoo "s/he runs fast", taapertaa "s/he runs toddling", väännättelee "s/he runs using much energy", all of them being structurally [run.3SG.PRS]. These and similar kinds of verbs that, which generally fall loosely under the term ideophonic vocabulary have traditionally been referred to as onomatopoetic, descriptive or expressive words in Finnish language studies (see Mikone 2001; Anttila 1977). Their lexical meaning focuses on the manner of action. This vocabulary is often semantically more or less vague.

Finnish has a specific two-verb construction type called the Colorative Construction (hereafter, $\mathrm{CoC}$ ). It was so named by the Finnish dialect researcher Ahti Rytkönen (1937). Even though the CoC is relatively infrequent in texts (see below), it has some identifiable structural characteristics. In example (1), we can see that the infinitive (mennä) is a semantically "neutral" verb denoting the type of action in question, while a 
"colorative" (COL) or ideophonic finite verb (such as körötteli) denotes how the motion is performed.

(1) Ukko [men-nä köröttel-i $]_{\mathrm{COC}}$ hevose-lla kirko-lle (fabricated) old.man go-INF COL-PAST.3SG horse-ADE church-ALL

'an old man went in a leisurely manner and without haste on horseback to church'

The infinitive is (almost) always the A-infinitive form, which is the verbal form used in Finnish dictionary entries. Grammatical (inflectional) markings are associated with the colorative verb, depending on the syntactic position of the CoC. ${ }^{1}$ The most usual word order is INF + COL (see ex. 1). Other formal parallel examples would be seistä törrötti 'stood jutting', potkaista sätkäisi 'kicked suddenly', juosta jolkotteli 'ran leisurely (without any hurry)' (see also Jarva \& Kytölä 2007).

As Jarva and Kytölä (2007) and my own data show, the CoC principally has four potential synchronic variants, depicted in Table 1. Rows in Table 1 differ according to finiteness, and columns differ according to word order. The word order may differ (cf. (i), (iii) vs. (ii), (iv)) as well as the inflection of the neutral verb, according to finiteness (cf. (i), (ii) vs. (iii), (iv)). From now on, I will refer to the type (i) as INF + COL, to the type (ii) COL + INF, to the type (iii) FIN + COL and to the type (iv) COL + FIN. Moreover, examples like *ukko men-i körötel-lä [ukko.NOM go-PAST.3SG COL-INF] are ungrammatical and they do not emerge from the empirical data, since only the neutral verb (mennä) can be inflected according to finiteness. The colorative verb is always in finite form (whenever the $\mathrm{CoC}$ is a predicate).

Table 1. Four potential variants of the CoC

\begin{tabular}{|c|c|}
\hline $\begin{array}{ll}\text { (i) } \mathrm{INF}+\mathrm{COL} & \\
\text { men-nä } & \text { köröttel- } i \\
\text { go-INF } & \text { COL-PAST.3SG } \\
\end{array}$ & $\begin{array}{l}\text { (ii) } \mathrm{COL}+\mathrm{INF} \\
\text { köröttel-i }[\ldots]^{*} \text { men-nä } \\
\text { COL-PAST.3SG } \text { go-INF } \\
\end{array}$ \\
\hline $\begin{array}{l}\text { (iii) } \mathrm{FIN}+\mathrm{COL} \\
\text { men- } i \quad[\ldots] \text { köröttel- } i \\
\text { go-PAST.3SG } \\
\text { COL-PAST.3SG }\end{array}$ & 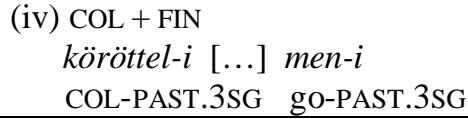 \\
\hline
\end{tabular}

From the cognitive-constructional point of view, the peculiarity of the $\mathrm{CoC}$ is that the grammatically prominent verb is semantically background-like and vice versa (see a 
parallel phenomenon in this respect in Jong-Bok Kim 2012). The colorative verb is grammatically prominent because it takes the morphological coding, that is, suffixes generally associated with finite verbs; yet semantically, it is more or less backgrounded, since it primarily designates the manner of action. Meanwhile, the infinitive is grammatically less prominent because it is in non-finite form. However, semantically, the infinitive denotes the type of action in a neutral and general way (e.g., motion in ex. 1). It represents the overall action frame and hence, can be understood as semantically prominent. The colorative verb characterizes or specifies and usually emphasizes in some way adverbial how-meanings of that very same action (e.g., 'leisurely and without haste' as in ex. 1). In this sense, there is a rather clear division of functional labor between the verbal elements of the CoC. In sum, this synsemantic nature is synchronically very much a semantic motivation of the $\mathrm{CoC}$ as a productive and conventional verb construction in Finnish.

Nominal expressions like poja-n.kloppi [boy-GEN.boy.NOM] 'a young boy who behaves badly' function in a similar way. This example consists of a neutral noun in the genitive case (pojan), designating the entity type in question, that is [+human, +male, +young], while a colorative noun (kloppi) designates with its lexical meaning the kind of boy in question, i.e., 'a young, badly behaving lad'. The synsemantic character of the construction is due to the nature of the colorative vocabulary. Denotatively, such expressions are so clearly manner-related or, in terms of nouns, adjective-like, that usually they are more comprehensible when they occur in company with other words. Exactly in this relative sense, A-infinitive verbs in CoCs can be comprehended as neutral. These verbs name an action frame that is semantically modified by manner meanings of a colorative verb. The lexical semantic relationship between the Ainfinitive verb and the colorative verb is that of hyponymy and hypernymy.

Finnish colorative verbs are very often lexicalizations and lexical conventionalizations from sound-symbolic or ideophonic roots, being onomatopoetic, imitative and somewhat descriptive in nature. For example, the verb hihi-tt $\ddot{a}$ - $\ddot{a}$ means 'to laugh snickering or giggling', where hih(i) represents an imitation of laughter (hi-hi-hi-hi), and $-t t \ddot{a}$ - is a derivational causative verbal suffix (- $\ddot{a}$ is an infinitive suffix). In particular, 
dialectal data show that colorative verbs can be relatively stable and are widelyrecognized by native speakers when conventionalized, (2) or they may be more regionally distributed when bounded by some dialect area (3). According to the SMS corpus (see Section 2), the verb kitvetellä seems to be regionally bound to eastern dialects or Northern Savolax. Sometimes, colorative verbs are even occasional lexical formatives because of the relatively free word formation schemas available in the colorative vocabulary, e.g., hehettää hahattaa hohottaa 'to laugh' $<h \mathrm{~V}_{\mathrm{i}} h \mathrm{~V}_{\mathrm{i}} t t a ̈$ - $(\mathrm{V}=$ vowel). Both (2) and (3) have slight semantic differences and idiosyncrasies, which are not always easy to define out of context.

(2) jolkottaa 'to run slow and in a relaxed way'

(3) kitvetellä 'to run slow and in a relaxed way' (SMS, s.v. kitvetellä)

The other form of occasionality in colorative verbs comes from their manner-focusing semantics. For example, the colorative verb ahkuta (see SMS, s.v. ahkuta) forms a CoC with verbs of motion (4a) and devouring (4b), and with a verb describing weather (4c). ${ }^{2}$

(4a) Savu-a tul-la ahkua-a unni-sta (fabricated) smoke-PAR come-INF COL-PRS.3SG oven-ELA 'Thick smoke comes from the oven.'

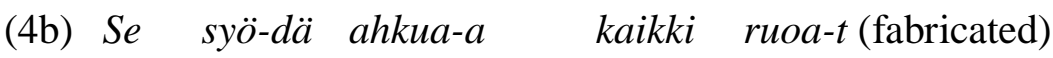
$\mathrm{s} /$ he eat-INF COL-PRS.3SG all food-NOM.PL 'S/he eats greedily all the food.'

(4c) Ulkona tuul-la ahkua-a kovasti (fabricated) outside blow-INF COL-PRS.3SG greedily 'It is blowing hard outside.'

Basically, ahkuta vaguely denotes the manner of action in general, and only because of that is it able to form a $\mathrm{CoC}$ with verbs of agentive and non-agentive actions, as well as with motion and non-motion verbs. In this respect, kitvetellä (3) is similar: juos-ta pala- $a \sim$ sata-a kitvettele-e [run-/burn-/rain-INF COL-PRS.3SG]. This is the very reason or the functional explanation for the CoC-construction to exist. The neutral A-infinitive verb specifies the overall frame, which is then semantically modified by the colorative verb. ${ }^{3}$ 


\subsection{Aims and organization}

The aim of this paper is to describe and demonstrate the grammaticalization of the CoC. The genesis of the $\mathrm{CoC}$ is an example of constructionalization, in the sense that a new construction emerges as both the form and the function of the existing expression type changes (see Rostila 2004; Traugott \& Trousdale 2014: 22). In this respect, constructionalization of the $\mathrm{CoC}$ differs from constructional changes that concern only certain features of an existing construction, such as only form or only meaning. The process of constructionalization is gradual in a two-fold way: First, syntagmatic reanalysis goes through semantic ambiguity, since the morphophonological changes are themselves gradual. Second, as reanalysis is brought to a close, it establishes a new paradigmatic slot in a grammar that can then expand gradually via analogy. This twofold gradual constructionalization of the Finnish $\mathrm{CoC}$ is the primary focus of this paper.

The organization is as follows: In Section 2 the dialectal data on which the research is based will be introduced. Traditionally, grammatical variation has been seen as a marker of potential change in a language, but in a similar way it can be seen as evidence for past changes as well. This is obvious in the current variation of the Finnish $\mathrm{CoC}$, and for that reason, data from dialectal and colloquial registers are essential. In Section 3 the theoretical basis of the research will be introduced. There are two central issues here: 1) Construction Grammar offers excellent opportunities to describe explicitly the gradual nature of grammatical changes including the relevant formalization, and 2) grammaticalization in general can be seen as based on the cyclic character of changes, i.e., changes usually affect several ranks in a grammar (see Fig. 1). Section 4 presents the current research and is divided into subsections: in 4.1, previous suggestions on the possible diachronic development of the $\mathrm{CoC}$ will be discussed (4.1.1), after which I will present my proposal for a potentially reconstructed proto-CoC (4.1.2). In section 4.2, 
the constructionalization process of the $\mathrm{CoC}$ will be explained. Section 5 summarizes the outcome of the analysis.

\section{Data}

The data for this paper come from three different sources of dialectal Finnish. These can be seen in Table 2 along with the number of tokens of the $\mathrm{CoC}$ gathered from each corpus.

Table 2. Tokens of the CoC in the LA, DMA and SMS corpora

\begin{tabular}{c|c} 
Corpus & $\mathrm{n}(\mathrm{CoC})$ \\
\hline Finnish Syntax Archive (LA) & 84 \\
\hline Digital Morphology Archive (DMA) & 408 \\
\hline Digital Dictionary of Finnish Dialects (SMS) & 1249 \\
\hline$\sum 1741$
\end{tabular}

The total number of CoCs in these data consists of 1,741 examples. Because of the search criteria, the LA corpus (Lauseopin arkisto) ${ }^{4}$ and the DMA corpus (Digitaalinen muoto-opin arkisto $)^{5}$ contain mostly CoC types (i) INF + COL and (ii) COL + INF (see Table 1). In the SMS corpus (Digitaalinen Suomen murteiden sanakirja), there are only a few effective search constraints available for the present topic. ${ }^{6}$ The SMS is actually a digitized version of the printed volumes of Suomen murteiden sanakirja (Dictionary of Finnish Dialects). I have used volumes $1-8$ of the SMS, which cover the alphabetical range $a$-kurvottaa ('a-to laugh-COL/to lie-COL'). Consequently, all CoC types (i-iv) are in principle available, but the two finite variants (FIN + COL $\sim \mathrm{COL}+\mathrm{FIN}$; cf. ex. 1) are found only rarely (see also Jarva \& Kytölä 2007: 242).

By and large, all three corpora rely on very different compositions and usage purposes. However, they have been founded on principles common in traditional dialectology, namely, informants have largely been the elderly people in order for the dialectologist to be able to gather sufficiently "original, proper and unbiased" dialect speech, which is also "rich in content and fluent without articulatory setbacks" - to use the common characterization in traditional dialectology. The LA, DMA, and SMS 
corpora represent all dialects spoken in Finland in the twentieth century. In this respect, the SMS represents the oldest material, gathered mostly during the $1920 \mathrm{~s}-40$ s by linguistic fieldworkers using printed questionnaires, while the other two resources are based on interviews with dialect speakers, largely during the 1950s-70s (LA) and the 1960s-80s (DMA). In addition, most of my data, i.e., DMA and SMS, lack a broad linguistic context. The genre in LA is basically interview material consisting of long narrative episodes.

The other crucial notion is that, of the three corpora, only one, LA, is suitable for making proper statistical analyses. With data from the LA corpus, for example, it is possible to count frequencies of a certain language phenomenon or even to use other, more sophisticated quantitative methods. The size of the LA corpus is $1,194,843$ words. Neither the DMA (841,755 words) nor the SMS corpus can be used for these methods. However, I find it necessary to represent in numbers how many empirical examples (instances not fabricated by the author's introspection) there are as well as their distribution with respect to the basic types of $\mathrm{CoC}$ (see Table 1). Basic quantitative descriptions provide necessary elementary knowledge of the phenomenon, even if elegant statistical methods (that is, explanatory and predictive) cannot be applied.

According to previous research, however, narrative texts seem to be a kind of default context for the $\mathrm{CoC}$ as a prominent idiolectal choice of the individual language user (see, for example, Heikkinen \& Voutilainen 2009, and the references there). What is worth pointing out in particular is that the CoC appears more frequently in the spoken language than in the written language (Ikola et al. 1989: 304). Thus, LA, DMA and SMS are the most relevant corpora available. From the more general point of view, the dialect corpora are representative, especially when it comes to diachronic studies, as they show the full extent of variation within certain grammatical structures. However, it is obvious that the $\mathrm{CoC}$ is highly infrequent, even in dialects, despite its otherwise prominent character in narratives. According to the LA corpus, in dialect speech only 0.05 percent of all clauses (one clause out of 2,000) include the $\mathrm{CoC}$, while with modal verbs, the A-infinitive (e.g., pitää men-nä 's/he has to go-INF') occurs in approximately 
0.25-0.35 percent of all clauses (2.5-3.5 clauses out of 1,000) (see also Ikola et al. 1989: 304; Herlin, Leino, \& Visapää 2005: 19).

\section{Theoretical basis}

In this paper, Construction Grammar $(\mathrm{CxG})$ is used as the main theoretical framework (see, for instance, Fillmore \& Kay 1995; Fried \& Östman 2004; Boas \& Fried 2006; Goldberg 1995, 2006). The following general characteristics favor applying the constructional framework here with certain ideas of grammaticalization (or grammaticization) theory (e.g., Lehmann 2002; Traugott \& Heine 1991; Heine, Claudi \& Hünnemeyer 1991; Bybee 2010). First, CxG is a sign-based grammar model that takes the notion of a grammatical construction (that is, the $\mathrm{CoC}$ ) as the basic unit of linguistic analysis (see Fried \& Östman 2004: 12). Thus, constructions are form-meaning pairings; hence, change in any aspect of a construction changes the whole linguistic structure. Second, $\mathrm{CxG}$ is also a usage-based model (see Barlow \& Kemmer 2000) that does not avoid parole. Here, usage-data are important precisely from the point of variation, as variation is generally considered a prerequisite for a linguistic change. Third, CxG's formalism is able to show many subtle features explicitly and demonstrate detailed piecemeal mechanisms involved in such parts of grammaticalization as bleaching, reanalysis and, analogical extensions (e.g., Fried 2009: 263).

Combining principles of grammaticalization and $\mathrm{CxG}$ is not unheard of (as examples, see Closs Traugott \& Trousdale 2010, 2014; Bergs \& Diewald 2008; Diewald 2007; Traugott 2008a, 2008b; Noël 2007; Rostila 2006). However, it is still a relatively new approach. $\mathrm{CxG}$, as mentioned, offers some explicit formalization tools for performing language change. Moreover, grammaticalization principles are needed to give theoretical support to internal reconstruction (see Ringe 2008; Anttila 1973: 317), which needs a full account of synchronic structural variation as shown by dialect data.

Here, I will use the cyclic character of grammaticalization as a general frame when describing the development of the CoC. Figure 1 shows that the basic idea of 
grammatical change lies generally in the fact that changes tend to proceed throughout a grammatical system and exert their influence on different levels (ranks). Here, it is important to understand that, in principle, the outset for a change can be on any level in this cycle and that changes can go forward and have their influence on any level "above" or "below" the outset rank. However, according to the constructional approach, a change in any level of the cycle affects a construction holistically. Moreover, it is not generally necessary to consider grammatical changes dichotomously as either external or internal, that is, based always either on language usage and objectives in discourse or on an (autonomous) grammatical system. There are many kinds of grammatical changes, such as morphological and semantic changes, syntacticization, lexicalizations, and so on; these can have different "vegetative points" in the rank hierarchy, depending on the individual language and phenomena in question.

Figure 1. Grammaticalization cycle $\ldots \rightarrow$ discourse $\rightarrow$ syntax $\rightarrow$ morphology $\rightarrow$ morphophonemics $\rightarrow$ (zero) $\rightarrow$ morphophonemics $\rightarrow$ morphology $\rightarrow$ syntax $\rightarrow$ discourse $\rightarrow \ldots$

Figure 1 does not represent any one model of grammatical change, but as can be seen, it is reminiscent of Givón's (1979: 208-209) discourse-based notion of the cyclic character of syntacticization. However, Givón's idea is that syntactic structures are always based on pragmatics, that is, they are crystallized discourse patterns emerging through routine usage. As Givón puts it (1979: 232), "pragmatics gives rise to syntax, syntax in turn gives rise to grammatical morphology, which then decays via phonological attrition.” From Givón's point of view, grammatical change always proceeds in the same order, from discourse to the lower ranks. However, as I see it, there is no single or strict model for grammatical change as a gold standard except perhaps some general principles of grammaticalization (e.g., unidirectionality, structural bleaching, and the like). Instead, some changes may be seen more as discourse-based (such as clefting in syntax), while others may be seen as more system-based (for instance, changes in case systems). These perspectives on language change represent different sides of the same coin. Different changes also involve different time scales. In principle, most historical processes are ongoing, yet language users are at any given 
point in time only subliminally aware of these processes, driving synchronic (natural) systems to infinite variationist dynamism (see also, e.g., Bybee 2010).

I will use the grammaticalization cycle proposed in Figure 1 to present my theory of the development of the CoC. The benefit of using the cycle is that it is neutral with regard to different theoretical orientations (such as formalism and functionalism), but principally it takes the whole language into account. The idea of a cycle is general enough both to cover all ranks in a language and to enable the description of different linguistic phenomena.

\section{Grammaticalization of the $\mathrm{CoC}$}

\subsection{Some historical background: The proto-CoC}

In this section, I will explain some of the relevant background for the grammaticalization process. First, in section 4.1.1, I will present Jarva and Kytölä’s (2007) ideas on the development of the CoC, and then in 4.1.2, I will formulate my own suggestion for the proto-CoC.

\subsubsection{On previous research}

At the end of their article "The Finnish Colorative Construction and Expressivity," Jarva and Kytölä (2007) briefly "attempt to sketch out some factors which may explain how the CC $[=\mathrm{CoC}]$ has developed." Their line of reasoning (as set forth on pp. 268269 ) is two-fold. First, the authors compare three different variants of the CoC: type (i) INF + COL, type (ii) COL + INF, and type (iii) FIN + COL (see Table 1). Their main idea is to determine which of these types could historically be the original variant. Since asyndeton is known to be old and widely distributed among Finno-Ugric languages (Karelson 1958), type (iii) FIN + COL, would for that reason be a good candidate for the most archaic variant. 
However, there are some reservations about drawing this conclusion. The most obvious is the question of how the other two variants would have developed on the basis of (iii) FIN + COL, as, according to Jarva and Kytölä (2007: 268), "some explanation is needed why a neutral verb has changed to a non-finite form;" in other words, why type (iii) FIN + COL changed into type (i) INF + COL and then further into type (ii) COL + INF. I suggest that this was not the case. First, that kind of development is not very natural in language change. Natural grammatical changes seldom make such leaps. Second, there is no empirical evidence for such a progression.

Although it is true that there can be syncretism between some A-infinitive forms and 3rd person singular present verbs in some Finnish dialects, especially in the written language (see example 5a, where kantaa retuuttaa can be interpreted either as type (i) $\mathrm{INF}+\mathrm{COL}$ or type (iii) FIN + COL CoC), syncretism cannot be regarded as a historical link demonstrating the grammaticalization of the $\mathrm{CoC}$. This syncretism is a much later development which occurred long after the actual grammaticalization of the $\mathrm{CoC}$. In fact, it is not clear how established the asyndetic two finite verb variants, that is, types (iii) FIN + COL and (iv) COL + FIN, have ever been, as expressions with loose paratactic verb chains also occur in the spoken language (see example 5b, where the comma after näkkyy indicates a short pause in speech).

(5a) Karhu kanta-a retuutta-a pentu-j-a-an pesä-lle (fabricated) bear.NOM carry-INF COL-PRS.3SG cub-PL-PAR-3PX den-ALL carry-PRS.3SG

'A bear carried dangling his/her cubs to a den.'

(5b) mikä kumma siellä näkky-y, huamotta-a (SMS) what strange.NOM there be.visible-PRS.3SG COL-PRS.3SG 'What on earth there is, looming like a ghost.'

That said, I would argue that variant (iii) FIN + COL, even though it can be seen as connected to the variants (i) INF + COL and (ii) $\mathrm{COL}+\mathrm{INF}$, would not be the original outset for the grammaticalization of the CoC.

Second, after Jarva and Kytölä (2007: 269) propose that variant (ii) FIN + COL is older than variant (i) INF + COL (see below), they compare variant (i) to other Finnish 
infinitive structures and suggest that the $\mathrm{CoC}$ "has its origin in infinitive clauses rather than in asyndetic juxtaposition." The next quotation elucidates their argument (see Jarva \& Kytölä 2007: 269):

How is it possible that an expressive construction $[=\mathrm{CoC}]$ has adopted the same syntactical structure as modal, permissive and otherwise abstract infinitive clauses? To some extent the infinitive verb could be understood as an explanation or a specification of the finite verb; therefore the infinitive clause minä tahdoin mennä 'I wanted to go' $[--]$ could be paraphrased as

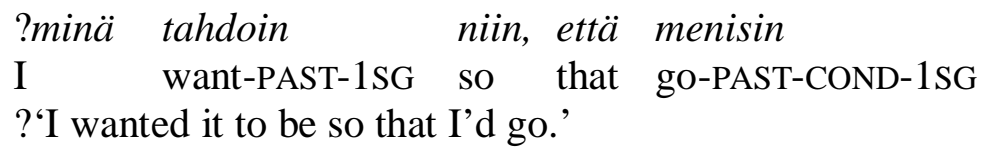

Similarly, the CC [= CoC] susi lotkotti mennä 'the wolf-COL [went relaxed and sluggishly, $\mathrm{MH}]^{\prime}[--]$ could be paraphrased as

(63) susi lotkotti niin, että se meni wolf COL-PAST-3SG so that it go-PAST-3SG

'the wolf COL-ED so that it went.'

Whatever the development has been, variant (a), kaatua tupsahdin [= type (i) INF + $\mathrm{COL}]$, is its end point. ${ }^{7}$

Now, as reasonable as it would be to compare syntactic similarities between infinitival structures, in light of the above quotation it is hard to see the diachronic connections invoked between them. Comparisons are simply too granular and general. Rather Jarva and Kytölä's comparisons (above) represent synchronic paraphrases more than a diachronic development. As early as 1880, the renowned Finnish scholar E. N. Setälä, in his Suomen kielen lauseoppi (Finnish Syntax), had a similar idea about "an infinitive of relationship" in his analysis of the CoC: Hän juosta hölköttää 'S/he runs in a slow and relaxed manner' = hölköttää juoksemisen suhteen 'As for running, s/he lollops' (Setälä 1880, s. v. Nominaalimuodot [Nominal forms]). It is possible that other infinitive structures have had their impact on the development of the $\mathrm{CoC}$ at some point, but it is unlikely that this occurred in the early phases of the process. It is more likely that the Finnish infinitive system developed as a whole, and for this reason the same infinitive functions in a similar way in relatively different infinitive structures, which enables paraphrasing as well. 
All in all, the above-mentioned descriptions are reasonable enough, but they still leave many open questions, such as how the current $\mathrm{CoC}$ might have gradually developed structurally and functionally from clausal expressions. Near-constructions (such as types (iii) FIN + COL and (iv) COL + FIN) and synchronically comparable paraphrases cannot on their own adequately demonstrate the actual historical development of the CoC. Possible historical links between paraphrased expressions remain primarily implicit. Thus, even though Jarva and Kytölä (2007: 269) show genuine interest in a historical explanation, their purely synchronic description still remains too brief and speculative from a diachronic point of view, as they themselves admit.

\subsubsection{Reconstruction of the proto-CoC}

Jarva and Kytölä's (2007: 269) idea that variant (ii) COL + INF is the oldest (although without the inference that the $\mathrm{CoC}$ would have its origin in other infinitive clauses) is supportable. This fact is a suitable starting point for outlining the relevant background for the development of the CoC. The first piece of evidence for the archaic character of the $\mathrm{COL}+\mathrm{INF}$ variant is that there can be other constituents between the verbs $(6 a-b)$.

(6a) si-llä sitä nylkytet-tiin sittek kääntä-äs sitä pelto-o (LA) it-ADE EXPL COL-PASS.PRT then turn.over-INF that field-PAR 'with that it was turned over bit by bit, that field'

(6b) siält viilettä-ä $y$ ks niim punaise-s pusero-s tul-la (LA) there COL-PRS.3SG one very red-INE sweater-INE come-INF 'here comes someone with a very red sweater rapidly (straight ahead)'

As can be seen in examples (6a) and (6b), word order with COL + INF can be less coherent, because it allows other elements between verbs, and therefore it is a less grammaticalized variant as well. I find this to be one piece of evidence for the fact that type (ii) COL + INF is an older variant than the type (i) INF + COL.

Table 3. Word order variations of the $\mathrm{CoC}$ in the data

\begin{tabular}{|l|l|l|}
\hline & \multicolumn{2}{|c|}{ WORD ORDER } \\
\hline CORPUS & (i) men-nä köröttel-i & (ii) köröttel-i $[\ldots]^{*}$ men-nä \\
\hline
\end{tabular}




\begin{tabular}{|c|c|c|}
\hline & $\begin{array}{c}\text { go-INF COL-PAST.3SG } \\
\text { (iii) } m e n-i[\ldots] \quad \text { köröttel- } i \\
\text { go-PAST.3SG COL-PAST.3SG }\end{array}$ & $\begin{array}{c}\text { COL-PAST.3SG go-INF } \\
\text { (iv) köröttel- } i \text { [...] men- } i \\
\text { COL-PAST.3SG go-PAST.3SG }\end{array}$ \\
\hline LA & 67 out of 84 hits & 17 out of 84 hits \\
\hline DMA & 359 out of 408 hits & 47 out of 408 hits \\
\hline SMS & 975 out of 1,249 hits & 274 out of 1,249 hits \\
\hline
\end{tabular}

$*[\ldots]=$ other constituents are possible between the verbs

The word order variant COL + INF represents a minority portion of my data, as can be seen in Table 3. Most of the dialectal material represents variant (i) INF + COL (or rarely (iii) FIN + COL), while variant (ii) $\mathrm{COL}+\mathrm{INF}$ (or rarely (iv) $\mathrm{COL}+\mathrm{FIN}$ ), is clearly in the minority. The variant (i) INF + COL is even more dominant in standardized written Finnish, while the inverse order is marginal, if not absent altogether, in standard registers (see ISK §450; Saukkonen 1966: 134). Moreover, the same can be said for variants (iii) $\mathrm{COL}+\mathrm{FIN}$ and (iv) FIN + COL, which have both verbs in a finite form (e.g., siit ko maattii pössöteltii [PASS.PRT] 'then we rested (and) chilled out', DMA). In the LA corpus, there are no examples of this type. In the DMA corpus, there are four instances of variant (iii), FIN + COL and none of variant (iv) COL + FIN. Likewise, from the SMS corpus, a total of 200 cases can be found, and the majority of them are type (iii) FIN + COL.

The argument concerning word order can be strengthened with evidence from other Balto-Finnic languages, as shown in the following examples ( $7 \mathrm{a}-7 \mathrm{e})$ :

(7a) siel vain hapute-ttih juosta (Karelian 2 out of 19) (KKSK) there just COL-PASS.PRT run-INF

'there we/they just ran quickly'

(7b) paukaiž ambu-da (Ludian 7 out of 21)

(Virtaranta 1986: 154) COL.PRT.3SG shoot-INF

's/he shot with a blast'

(7c) röpöta-b bas-ta bepsa-ks (Vepsian 10 out of 15)

COL-PRS.3SG speak-INF Vepsian-TRA

(Kettunen 1943: 155-158)

's/he speaks Vepsian in an unclear way'

(7d) hepoin hötsütä-b joos-sa (Votic 10 out of 15) (Posti 1980: s.v. hötsütäB) horse COL-PRS.3SG run-INF 'the horse ran in an easy manner' 


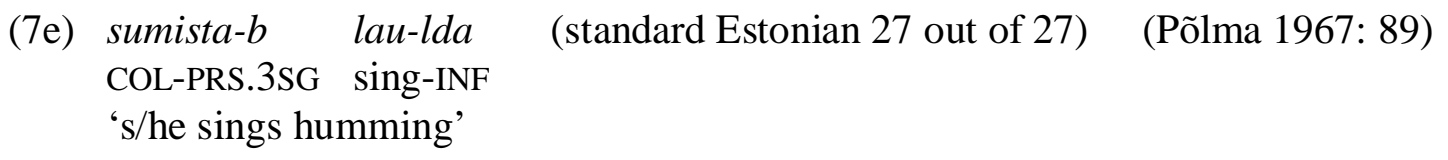

Examples (7a-e) represent variant (ii) $\mathrm{COL}+\mathrm{INF}$. Digits after the name of the language show how many cases of this variant exist compared to all instances of the $\mathrm{CoC}$ in that reference. Even though this material is scarce, it can be found in most Balto-Finnic languages: especially in Estonian (7e), and mostly in Vepsian (7c) as well as in Votic (7d). That Karelian (7a) and Ludian (7b) seem to have less of variant (ii) COL + INF is probably because the other instances are all finite variants (mostly FIN $+\mathrm{COL}$ ). (See also the data in Saukkonen 1966: 134-138.) One can thus conclude that variant (ii) COL + INF might be, historically, the original: this variant can be found in all Balto-Finnic languages in which the CoC occurs, whereas type (i) INF + COL cannot (cf. Saukkonen 1966: 137).

Concerning the outset of the grammaticalization of the $\mathrm{CoC}$, I have excluded finite verb variants (iii) FIN + COL and (iv) COL + FIN as unlikely original structures. Instead, I have argued that the less cohesive infinitive variant (ii) COL + INF without any necessary connection to infinitive clauses represents the oldest type. Jarva and Kytölä (2007: 268-269) attempted to outline some factors for the development of the CoC, but they did not take into account a particular diachronic aspect of the A-infinitive form. This concerns a certain morphophonemic phenomenon of the A-infinitive in current spoken Finnish. In examples ( $8 \mathrm{a}-\mathrm{b})$, the zeros $(-\varnothing)$ after the A-infinitive forms allude to this issue. As can be seen, in standard written Finnish (8a), there is nothing orthographically distinctive nor, in certain dialects (8b), is anything phonetically discernible.

(8a) Koirat juos-ta- $\varnothing$ jolkutt-i-vat takaisin koti-in. (standard Finnish, fabricated) dogs run-INF COL-PRT-3PL back home-ILL

'The dogs ran slowly and relaxed trotted back home.'

(8b) ihmist naura-a- $\varnothing$ rähäht-iit (DMA)

people laugh-INF COL-PRT-3PL

'people laughed out loud' 
However, in some contemporary dialects and in spoken Finnish in general, these zeros are still widely realized phonetically, as seen in examples $(9 a-b)$. Although this phenomenon is usually more or less inconspicuous for most speakers of current Finnish, it represents a diachronically significant grammatical trace of the development of the $\mathrm{CoC}$ (as well as other infinitive clauses with an A-infinitive form).

(9a) se kuol-ta-k kupsah-t (DMA)

it die-[INF $]^{\mathrm{x}}$ COL-PRT.3SG

'it s/he died abruptly'

(9b) savu nous-ta-? ?ängötti (DMA)

smoke rise-[INF] ${ }^{\mathrm{x}}$ COL-PRT.3SG

'smoke rose very slowly'

The morphophonemic zeros of the A-infinitive suffix in examples $(8 a-b)$ are realized in examples $(9 \mathrm{a}-\mathrm{b})$. They are glossed with the superscript $\mathrm{x}$. As a historical trace, this $\mathrm{x}-$ feature is realized in a way that depends on the phonetic context that follows. Briefly, when a subsequent morpheme (e.g., a lexical unit) begins with a consonant, the zero occurs as phonetically homorganic (as in ex. 9a), whereas when a subsequent morpheme begins with a vowel, the zero is realized as a glottal stop (as in ex. 9b). This can be considered a standard example of synchronic phonetic assimilation. ${ }^{8}$ (For more on this issue, see Itkonen 1964.)

The morphophonemic $\mathrm{x}$-feature described above is in fact assumed to be a historical trace of the Proto-Finnic terminal $* k$-lative case (see Hakulinen 1961: 76-78; Leino 2005: 109; Lehtinen 2007: 93; Ylikoski 2003: 213, 225; however, cf. Ylikoski 2011: $240,248,255-256)$. Hakulinen describes a few suffixes $\left(*_{-}, *_{-}, *_{-} n\right.$ and $\left.*_{-i}\right)$, all of which have been considered as previous motion or direction implying lative case forms. Furthermore, Hakulinen (1961: 76) presents examples such as toi vettä janoisten juoda $a_{\mathrm{INF}}$ 's/he brought water for the thirsty to drink', sopii tehdä $\ddot{\mathrm{INF}}$ 'it is all right to do so', paneutui maata ${ }_{\mathrm{INF}}$ 'put him-/herself to lie down', oli pudota $a_{\mathrm{INF}}$ 'was to fall' [bolding $\mathrm{MH}]$. Hakulinen argues that the original lative function is still evident here, even though a clear morphological marker no longer exists. 
connection to the Balto-Finnic $\mathrm{CoC}$, since these asyndetic structures represent looser syntagmatic verb expressions that do not build on constituency as do the prototypical Balto-Finnic CoC types (i) INF + COL and (ii) COL + INF. This also implies that the diachrony of the CoC would not go back earlier than Middle Proto-Finnic.

Nevertheless, when it comes to ideophonic verbs in general, it is somehow symptomatic that they often turn up with another explanatory neutral verb.

\subsection{Constructionalization: From proto-CoC to the current $\mathrm{CoC}$}

In this section, I present my view of the constructionalization of the $\mathrm{CoC}$. The discussion proceeds diachronically from the proto- $\mathrm{CoC}$ to the pre-CoC and eventually to the modern CoC. Sections 4.2.1-4.2.4 follow the grammaticalization cycle and fit the concepts of reanalysis, analogy and diachronic micro-steps in the general frame of change with $\mathrm{CxG}$ formalization.

\subsubsection{Syntax $\rightarrow$ morphology}

Now that some relevant historical characteristics of the $\mathrm{CoC}$ have been introduced, it is possible to present an abstract structure representing the assumed original proto-CoC (Figure 2). Some basic principles of CxG's formal notation are adopted here from Fillmore and Kay (1995) and Fried and Östman (2004). According to Figure 2 and the reconstructed examples $(10 \mathrm{a}-\mathrm{c})$, the inventory of common characteristics of the proto$\mathrm{CoC}$ are as follows: the word order was COL + INF, the lative case of the infinitive indicated direction, the A-infinitive was an intransitive motion verb, and the colorative verb was semantically momentative. Here, I will use Figure 2 to go through these features along with some others.

Figure 2. The proto-CoC 


$$
\begin{aligned}
& \begin{array}{ll}
\text { syn } & {[\text { cat } \mathrm{S}]} \\
\text { sem } & \downarrow 1 \downarrow 2 \text { frame [CHANGE-ÖF-STATE] }
\end{array} \\
& \text { syn }\left[\begin{array}{ll}
\text { cat } & \mathrm{NP} \\
\text { gf } & \text { subj }
\end{array}\right] \\
& \text { sem role }[\theta<\text { agt; theme> }] \\
& \operatorname{lxm}[\text { ] } \\
& \begin{array}{c}
\text { syn }\left[\begin{array}{ll}
\text { cat } & \mathrm{V} \\
\text { fin }+ \\
\text { gf head }
\end{array}\right] \\
\text { phon *-AštA- } \\
\text { sem } \uparrow 1 \text { frame } \\
\text { [MOMENTATIVE } \\
\text { MOTION] }
\end{array} \\
& \begin{array}{l}
\text { syn }\left[\begin{array}{ll}
\text { cat } & \mathrm{V} \\
\text { fin } & - \\
\text { case } & \text { lat } \\
\text { gf } & \text { advl }
\end{array}\right] \\
\text { phon } *_{-} A-k \\
\text { sem } \uparrow 2 \text { frame } \\
\text { lxm } \quad[\text { MOTION }]
\end{array}
\end{aligned}
$$

The proto-CoC was not a fixed construction of a kind similar to the current $\mathrm{CoC}$. It probably permitted other words between the colorative verb and the A-infinitive in the same way as variant (ii) COL + INF permits other words in current dialects and spoken Finnish (e.g., käire vaa, painettiin sinnem mennä 'by walking, we pushed our way there', DMA). In a formalization, this could be indicated by an empty box between the verbal constructions with the so-called Kleene star $(*)$, but for ease of presentation, this has been left out in Figure 2. The box with the broken gray line denotes the proto-CoC as a whole. In addition, the syntactic analyzability between the elements was still apparent. The $k$-lative case was functional and productive (syn [case lat]), and the infinitive was a free adverbial (syn [gf advl]).

Perhaps the most important features of the proto-CoC as a construction were in its semantics. Originally, finite colorative verbs represented a morphologically closed verb class, namely, the momentative. This can be seen in the derivative suffix for the momentative (phon *-ǍstA- >-AhtA- in current Finnish; e.g., istahtaa 'to sit down for a short while', pyrähtä̈̈ 'to sprint') and its semantic frame MOMENTATIVE MOTION. The presumption that the colorative verb was momentative in the proto-CoC is based on the fact that non-momentative coloratives would have formed odd or ungrammatical syntagms with A-infinitives in *k-lative (e.g., *körötteli mennäk). Accordingly, the original semantic frame of the infinitive was presumably MOTION, since different motions and movements represent concrete, frequent, and perceivable events in the world. Thus, the proto-CoC as a whole was about intransitive motion of a volitional AGENT or a non-volitional THEME (note the value pool in the sem role $[\theta<\mathrm{AGT}$; 
THEME>]. What distinguished it from ordinary intransitive motion frames was the integration of the semantic frames of both the colorative verb ( $\uparrow 1$ frame) and the Ainfinitive ( $\uparrow 2$ frame). In Figure 2, this is indicated in the largest box by the notation $\downarrow 1 \downarrow 2$ frame. This frame integration takes place already within the proto-CoC box, but owing to lack of space, this information is represented only at the sentence level.

What is remarkable is that the semantic composite of the colorative and the A-infinitive frames was not (intransitive) MOTION nor was it MOMENTATIVE MOTION, but rather CHANGE-OF-STATE. One explanation for this would be that the finite colorative verb focused semantically on the precise culmination point between two subsequent states immobility (or stationary state) and motion, alternatively called motion 1 and motion 2 , respectively. Moreover, the momentative verb was inchoative by its aktionsart when combined with a motion-denoting A-infinitive in the $k$-lative case. Thus, when conceptualizing the proto-CoC sequence by sequence, we perceive a prototypical event in which a subject-NP is transferred from one state to another. As a state-of-affairs in the real world, these two stages are separated by an abrupt, colorative or ideophonicbased process. At the constructional level described in Figure 2, this "chunk of the world" was conceptualized as the semantic composition of the change (colorative) and the latter state (A-infinitive); hence, CHANGE-OF-STATE in the semantic frame.

This was the most characteristic semantic feature of the proto-CoC as a syntactic construction. First, it distinguished the proto-CoC semantically from other formally equivalent infinitival constructions like $\mathrm{V}_{\mathrm{FIN}}+\mathrm{INF}_{\mathrm{LAT}}$, such as tahtoo mennä 's/he wants to go', lupaa mennä 's/he promises to go', pitää mennä 's/he has to go', and so on. Second, it fit well with Goldberg's (1995: 4) general definition of a construction: semantic aspects of the proto-CoC cannot be predicted from its parts, but rather emerge from the whole. Third, the word order $\mathrm{COL}+\mathrm{INF}_{\mathrm{LAT}}$ of the proto-CoC was iconic in the sense of motivation; i.e., the linear order of two parts of this syntagm reflects the natural order of events in reality (Haiman 1980). The colorative verb represented a perceptually prominent momentary event between two different states, and the A-infinitive in the lative case designated the latter event, usually motion. The function of the $* k$-lative case 
was to indicate the subject's transition to the action or motion designated by the Ainfinitive.

It is crucial to understand that the interpretation of the current $\mathrm{CoC}$ did not fit the proto$\mathrm{CoC}$, because the $* k$-lative case was productive, and no caseless infinitive form yet existed. That is why the colorative verb and the A-infinitive form constituted a motivated linear syntagm whereby two successive events were conceptualized as separate. The reason that the MOTION frame has more than likely been the original context for the proto-CoC can be inferred from two factors. First, concrete spatial motion is perceptually prominent and experientially a very frequent event in the world. Second, the corpus data show that motion is also a single clear event type with the current CoC. In the LA corpus, 37 out of 84 A-infinitives are motion verbs, and even though the DMA corpus does not allow statistical methods, it is worth noting that almost half of its $\mathrm{CoC}$ examples are about motion. Common infinitives in the corpora are mennä 'to go', tulla 'to come', kävellä 'to walk', ajaa 'to drive', lyödä 'to hit', juosta 'to run', käydä 'to visit', istua 'to sit', pudota 'to fall', and tehdä 'to do, to make'.

Based on examples (10a-c), I have also argued that, in the proto-CoC, colorative verbs were originally momentative-inchoative. Since the function of colorative verbs in the proto-CoC was to express sudden change between two states - one inferred from the context and the other explicated by the A-infinitive - it is natural that onomatopoetic or other expressive verbs designating momentary events would have fulfilled that function. The derivative suffix *-Ašt $A$ - (currently - $A h t A$-) with its momentative meaning simply emphasized those characteristics. Consequently, colorative verbs focused on the perceptually most prominent part of the MOTION activity, namely, the starting point of movement or the change of state.

In sum, as described above and formalized in Figure 2, the proto-CoC was a syntactic expression that consisted of a momentative colorative finite verb and a motion verb in the infinitive form with $* k$-lative case. The meaning of this motivated (iconic) syntagm was a sudden change of state. It cannot be categorically denied with positive evidence 
that the proto-CoC would not have had historically motivated connections to the other infinitive constructions. Rather, the clearest evidence for grammaticalization from the proto- $\mathrm{CoC}$ to the current $\mathrm{CoC}$ comes from changes in the Balto-Finnic case system morphology. In the following section, I will clarify this development.

\subsubsection{Morphology $\rightarrow$ morphophonemics $(\rightarrow$ zero)}

In order to be able to give a plausible historical description of the $\mathrm{CoC}$, we need a wider perspective on the Proto-Finnic non-finite paradigm. That perspective is represented in Table 4. The table is largely based on Lehtinen (2007), but uses modified terminology by Ylikoski (2003) to move in a more typologically plausible direction (see also Haspelmath 2010). ${ }^{10}$

Table 4 presents only those reconstructed non-finite forms that are relevant to the current topic. These are infinitives in directional, internal and general locative case forms. Moreover, what emerged during the development from Middle Proto-Finnic (MPF) to the latest period of Late Proto-Finnic (LPF) and finally up to modern Finnish were new infinitival construction patterns. It would go too far afield from the central topic here to sketch even a general view of the development of those constructions, but a brief overview of the diachronic progression of non-finite case forms is nonetheless presented. In the MPF era, there were presumably fewer grammatical, non-finite forms which had multiple functions, meaning they were more polysemous according to current diachronic theories.

Table 4. The reconstructed historical paradigm of Balto-Finnic A-infinitive and MAinfinitive forms, ex. tulla 'to come' (see Lehtinen 1997: 93, 122, 124, 134; Ylikoski 2003: 203-205, 208, 212-213, 216-217).

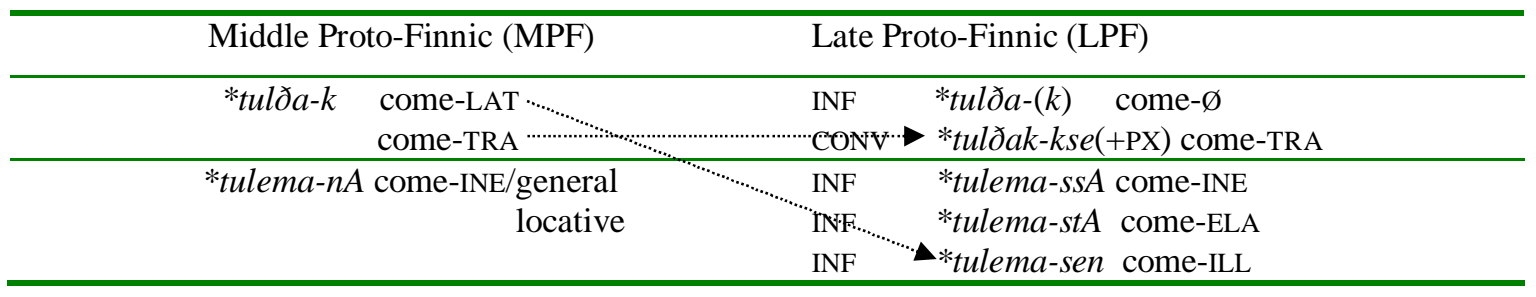


As time passed, the repertory of non-finites became re-structured so that some of the functions adopted distinct morphological forms (shown by the arrows in Table 4). The operative principle was a tendency toward the one form - one meaning principle, which constituted more symmetric subsystems within the non-finite paradigm (see also Ylikoski 2011: ch. 3). For example, MA forms became symmetric with regard to the internal local cases (illative 'to', inessive 'in', and elative 'from'). ${ }^{11}$

Even though it is not possible to depict the entire development of the Finnish non-finite paradigm, it is plausible to infer that the infinitive lative case was part of the bigger picture. Its historical fate (and subsequent loss) through semantic bleaching was the single most crucial factor in the grammaticalization process of the $\mathrm{CoC}$. Thus, to examine the historical development of the $\mathrm{CoC}$ as part of the paradigmatic changes in the system of non-finite case markings seems to be more fruitful than reasoning with paraphrases as in Jarva and Kytölä (2007: 269). Synchronically, the CoC might be a bit extraordinary compared to other non-finite constructions in Finnish, but its historical peculiarities cannot be derived in a straightforward manner.

The proto-CoC was one of those verbal chains whose A-infinitive with a terminal $* k$ lative was accompanied by a finite verb. Without going further into details of other nonfinite structures - additional background information can be found, for example, in Saukkonen $(1965,1966)$ and Leino $(2005)$ - it can be argued that the essential factor behind the historical change was a global re-structuring of non-finite case distribution during the MPF and LPF eras (see Table 4). With respect to the proto-CoC, this means that when the MA-infinitive's illative - illative being a crucial case form for building a symmetric subsystem within the local cases of the Balto-Finnic non-finite system emerged as a new infinitival form, it began to take over the functional field previously occupied by the $* k$-lative. ${ }^{12}$ This in turn led to a process in which the $* k$-lative began gradually to bleach, first semantically in becoming unproductive and then eroding structurally as well. As for the proto-CoC, the battle between the functionally overlapping infinitival forms gave rise to an ambiguity formalized in Figure 3.

Figure 3. Semantic ambiguity as input for grammatical reanalysis 


$$
\begin{aligned}
& \text { syn [cat S] } \\
& \text { sem } \downarrow 1 \downarrow 2 \text { frame [CHANGE-GSF-STATE] [MANNER-OF-MOTION] } \\
& \text { syn }\left[\begin{array}{ll}
\text { cat } & \mathrm{NP} \\
\text { gf } & \text { subj }
\end{array}\right] \\
& \text { sem role }[\theta<\text { agt; theme> }] \\
& \operatorname{lxm}[\text { ] } \\
& \begin{array}{l}
\text { syn }\left[\begin{array}{ll}
\text { cat } & \mathrm{V} \\
\text { fin } & + \\
\text { gf } & \text { head }
\end{array}\right] \\
\text { phon } * \text {-AštA- } \\
\text { sem } \uparrow 1 \text { frame } \\
\text { [MOMENTATIVE } \\
\text { MOTION] } \\
1 \text { [xm }[\text { ] }
\end{array}
\end{aligned}
$$

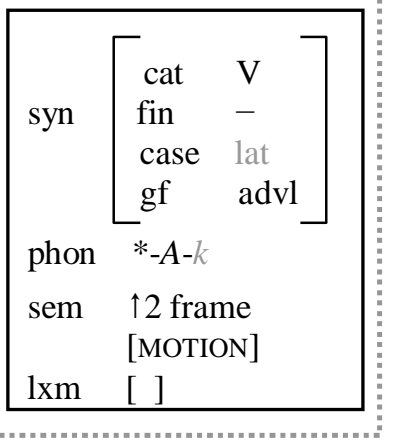

As the * $k$-lative was gradually pushed away by the MA-infinitive illative, it ended up in the continuum of piecemeal unproductiveness. This is marked by the gray font in Figure 3. There was a period in LPF when the construction could be interpreted in two different ways, either as the proto-CoC (see section 4.2.1) or as something which one may call the pre-CoC. For instance, example (10a), *koira pyräšti joostak, could be interpreted as 'a dog abruptly started to run' (the proto-CoC) or as 'a dog sprinted' (the pre-CoC). As already argued, the linear ordering of verbs in the proto-CoC had an isomorphic (i.e., motivated) relation to the perceived events in the real world. Its semantic frame was CHANGE-OF-STATE. The proto-CoC was iconic. The pre-CoC, however, was not, even though the order of elements remained unchanged. Rather, the pre-CoC with the motion-cum-manner interpretation became semantically more compressed than the proto-CoC. This means that the momentative colorative verb eventually began to modify MANNER qualities of the whole process represented by the A-infinitive, not just the transition between two qualitatively different stages. Its frame could thus also be interpreted as MANNER-OF-MOTION, as indicated in Figure 3.

At first, the semantic ambiguity of the proto- and the pre-CoC existed coincidentally without having any apparent impact on the linear surface structure COL + INF. Presumably, their interpretation depended on the context. Still, it is somewhat mysterious as to what precisely triggered the interpretation during the ambivalent period and how that happened. One possibility, although not very pronounced, could simply be pragmatic: interpretation was made solely according to the ongoing discourse situation by inference. However, regarding grammaticalization, the more important aspect to 
consider here is whether there was any semantic ambiguity at all, as this is the true fuel for reanalysis (see Bybee 2010: 136-150, 199). Moreover, it is important to note that the reanalysis itself was a gradual historical process: a rivalry between different case markings in non-finite verb forms led to constructional and functional ambiguity. This can be seen as the principle of economy in a language system: first, to make a functional distinction between the two forms, and second, to establish that same distinction. As for the grammaticalization of the $\mathrm{CoC}$ from a re-analytical point of view, this was the picture of the change. Regarding grammaticalization principles in general, it is not just synchronic structural variation that stands for a favorable basis of grammatical change, but also semantic ambiguity, which had evolutionary effects as well.

Reanalysis took place when functional overlapping developed into functional separation. In other words, the distinction emerged when the semantic ambiguity evolved into a real semantic difference. Accordingly, the MA-infinitive illative completely adopted the very same functional slot that had previously been governed by the infinitive with the $* k$-lative. Grammatical precedents for expressions such as those in the examples $(10 \mathrm{a}-\mathrm{c})$ can be found in Finnish and other Balto-Finnic languages, as the examples $(11 \mathrm{a}-\mathrm{c})$ clearly show.

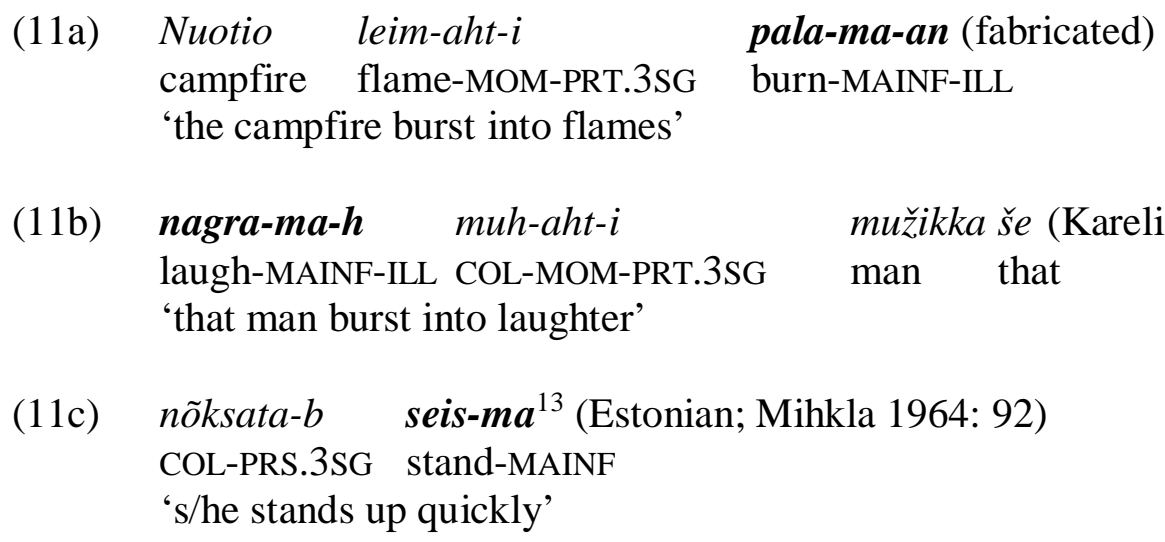

Although the proto-CoC had been a structurally somewhat loose and iconic verb chain, the pre-CoC became a more compact package after the aforementioned re-organization of the case system. This is demonstrated formally in Figure 4.

Figure 4. The pre-CoC as a new grammatical construction 


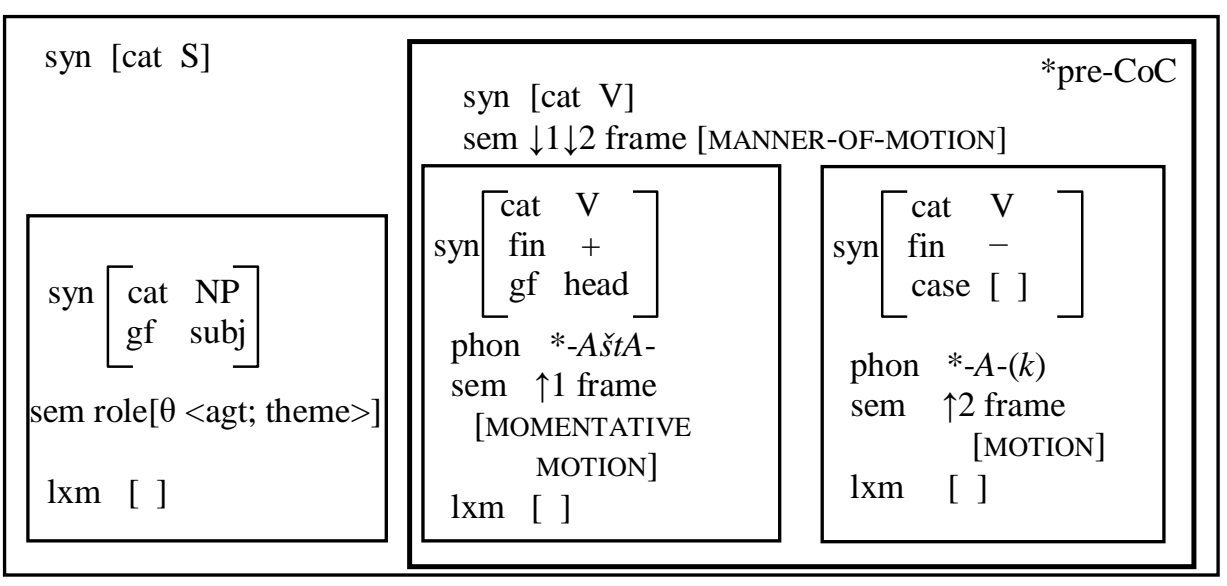

On the level of actual instances or constructs, any structural difference between the proto- $\mathrm{CoC}$ and the pre- $\mathrm{CoC}$ is not noticeable at first, simply because the * $k$-lative's structural erosion was slower than its actual becoming a functionally unproductive case. In Figure 4 , this situation is shown by putting the $* k$-lative within empty square brackets. Now the A-infinitive became a caseless verb form and syntactically unanalyzable (syn [case [ ] ]) as well. As the reanalysis finally took place, semantic ambiguity was lost, and the verbal chain was interpreted as a construction per definitionem, i.e., as a structural-functional Gestalt. This is indicated by the thick black line in the larger box representing the pre- $\mathrm{CoC}$ as a newly conventionalized grammatical construction. As has been proposed, this change was gradual.

In sum, the grammatical development from the proto-CoC COL $+\mathrm{INF}_{\mathrm{LAT}}$ to the pre-CoC $\mathrm{COL}+\mathrm{INF}$ was the consequence of a general rearrangement in the Balto-Finnic case system. The emergence of the MA-infinitive illative and the fading of $* k$-lative led to reanalysis; in other words, the previous meaning CHANGE-OF-STATE was gradually reinterpreted as MANNER-OF-MOTION. The unproductive $* k$-lative faded phonetically and became the morphophonemic x-feature of the A-infinitive (see footnote 8), which is not realized at all in written standard Finnish. Thereafter, in order to develop into the current $\mathrm{CoC}$, the pre-CoC underwent semantic extensions by analogy and by change of word order.

\subsubsection{Analogy and semantic extensions}


According to my data, MOTION is a prototypical frame for the $\mathrm{CoC}$, but there are other frames as well (see ex. 4b-c, 5b, 6a, 8b, 9a). The current $\mathrm{CoC}$ can be applied to any basic and commonplace actions such as eating, drinking, sleeping, sitting, standing, speaking, and so on and even to non-animate actions. The essential question is how these semantic frames reached the pre-CoC. Besides structural reanalysis, another crucial force of grammaticalization - analogy - played an active role in the further development of the pre-CoC (e.g., Hopper \& Traugott 2003: Ch. 3.5). A historical equivalent to the synchronic prototype and the source of the analogy can be called a host class (see Himmelmann 2004: 32). This is schematically represented in Figure 4 as the pre-CoC designated manner of motion. It was a constructional mold for similar verbal chains in semantic fields other than motion.

Next, I will argue that the gradual development occurred as follows: as described above, the proto-CoC preferred momentative (and inchoative) colorative verbs, which focused on the culmination of two separate stages (Figure 2). After the $* k$-lative became unproductive, the semantic relationship between the colorative verb and the infinitive became more compact, and the semantics of this syntagm gradually began to designate MANNER-OF-MOTION (Figure 4). The outcome of reanalysis enabled verbs other than momentative-inchoative motion verbs to act as colorative verbs in the pre- $\mathrm{CoC}$ (see examples $(12 a-b))$.

\begin{tabular}{|c|c|c|c|c|c|}
\hline$(12 a)$ & $\begin{array}{l}\text { sija-t ne } \\
\text { pig-NOM.PLthey } \\
\text { "pigs wandered-c }\end{array}$ & $\begin{array}{l}k \ddot{a} y v-v \ddot{a} \\
\text { walk-INF } \\
\text { COL there d }\end{array}$ & $\begin{array}{l}\text { jöynättel } \\
\text { COL.PST.3SG } \\
\text { Iring summers }\end{array}$ & $\begin{array}{l}\text { uppokesät } \\
\text { summers }\end{array}$ & $\begin{array}{l}\text { tuola (LA) } \\
\text { there }\end{array}$ \\
\hline 2b) & $\begin{array}{l}\text { hevose- } t \\
\text { horse-NOM.PL }\end{array}$ & $\begin{array}{l}k \ddot{a} y-r \ddot{a} \\
\text { walk-INF }\end{array}$ & $\begin{array}{l}\text { lont-i } \\
\text { COL-PST.3SG }\end{array}$ & $\begin{array}{l}\text { oma-a } \\
\text { own-PAR }\end{array}$ & $\begin{array}{l}\text { aika-a-nsa (LA) } \\
\text { time-PAR-PX. }\end{array}$ \\
\hline
\end{tabular}

This was the first analogical extension of the pre-CoC to motion verbs in general, and it strengthened the MOTION frame as characteristic and prototypical of the $\mathrm{CoC}$. It also established the MOTION frame as a host class for further analogical expansions. If we consider Figure 4 again, it can be seen that the colorative verbs' phonological value (i.e., phon *-AštA-) and semantic frame (i.e., MOMENTATIVE MOTION) were no longer valid. 
The second semantic extension by analogy was the progress that also enabled frames other than pure motion to be applied in the pre-CoC. In this respect, there are two competing explanations. Saukkonen (1965: 58) argued that, as a productive case, the $* k$ lative had two original meanings: concrete spatial direction (i.e., lokaali 'local') and abstract direction or purpose (i.e., finaali 'final') 'in order to do something' (e.g., *syödäk 'in order to eat'). According to Saukkonen (1965: 239), these functions could be equally old. Traces of the final function can be found in older written Finnish as well as in current Finnish. Example (13) represents a Finnish permissive construction, which is supposed to have had ambiguous semantics (see Leino 2005: 106-112).

\begin{tabular}{|c|c|c|c|}
\hline Kalle & omena- $n$ & Ville- $n$ & $s y \ddot{o}-d \ddot{a}($ fabricated $)$ \\
\hline Kalle & give-PRS.3SG apple-GEN & Ville-GEN/DAT & eat-INF \\
\hline
\end{tabular}

Now, if we suppose that a) examples such as (14a-b) existed between the proto- and the pre-CoC era along with the COL + INF type motion variants and $b$ ) that the $* k$-lative was still somehow productive, we have to infer that the A-infinitive's * $k$-lative case could not reasonably be interpreted as local, but either as final (i.e., PURPOSIVE) or as the newly established pre-CoC. The first interpretation would require the PURPOSIVE $* k$ lative to have gone through a similar process of gradual reanalysis as spatial protoCoCs, while the second interpretation would require new innovations to have been made by analogy with the pre-CoC (see Figure 4). I prefer the latter explanation.

(14a) sepä-t nalakuttel ${ }^{j}$ takko-on ne (LA) smith-NOM.PL COL-PST.3SG hammer-INF them ?'smiths used to COL-ed in order to hammer them' (PURPOSIVE) 'smiths used to hammer-COL them' (CoC interpretation)

(14b) si-llä napsauttan-neet siihel lyy-äs sitten(LA) it-ADE COL-PCP.PL there hit-INF then ?'they had COL-ed there in order to hit it [with an axe]' (PURPOSIVE) 'they had hit-COL there with it [an axe]' (CoC interpretation) 
There are several suspicious issues that lead one to suppose that probably the final or PURPOSIVE meaning of the $* k$-lative did not have a role in the grammaticalization of the CoC. First, as Saukkonen (1966: 139) put it, it is not always clear whether the $* k$-lative should be interpreted as local or as final. This is not a remarkable problem as soon as usage situation and contextual features disambiguate interpretations effectively. But, second, if the local meaning of the $* k$-lative was not available as in examples $(14 \mathrm{a}-\mathrm{b})$, this does not guarantee that the final interpretation would not be more or less unnatural. Saukkonen's (1966: 136) examples, such as älä pölpötä puhua 'do not prate in order to talk' and hän taapertaa mennä 's/he toddles in order to go', in my opinion, represent the kinds of forced interpretations (preceded by a question mark in translations) similar to those in examples $(14 a-b)$.

Third and most important, the purposive meaning of the $* k$-lative requires extra meaning, namely, intentionality. The original spatial (local) meaning of the proto-CoC designated the MOTION frame, so that the colorative verb represented the inchoative aspect of the motion and the A-infinitive represented the actual motion type in question (ex. 10a-c). The function of the $* k$-lative was to explicate the transition from one state to another, which was represented by the A-infinitive verb. Both in the spatial proto$\mathrm{CoC}$ and in the spatial pre-CoC, the colorative motion and the motion designated by the A-infinitive were contained in the MOTION frame in general. The main result of reanalysis then was the fading of the inchoative aspect and the fact that the colorative motion came to be contained in the MOTION frame of the A-infinitive in particular (cf. Figure 3 and Figure 4). This kind of containment in the same general frame is lacking in the intentional (final) meaning of the $* k$-lative. Also the semantic hyponymy relation of the colorative and the A-infinitive does not prefer the * $k$-lative's final function. Usually in intentional contexts, one action in one frame is conducted in order to develop chances for some other action to occur in the other frame (ex. 13). These are the main arguments for why interpreting examples such as $(14 \mathrm{a}-\mathrm{b})$ as PURPOSIVE seems unnatural.

For these reasons, I do not follow Saukkonen (1966: 134-141), who maintained that the final (PURPOSIVE) meaning of the $* k$-lative must have had a central role in the grammaticalization of the CoC. Instead, I prefer the idea that, as soon as the pre-CoC 
emerged, it extended analogically to frames other than MOTION as well, and prior to this model, non-motion CoCs did not appear. This does not mean that the final function of the $* k$-lative did not exist at all, but rather that it was more apparent in the other verb syntagms than in the proto-CoC (ex. 13). Moreover, examples such as (15), where the verb syntagms could possibly be analyzed in all three ways, depending on the context between the proto- and the pre-CoC period, were surely marginal.

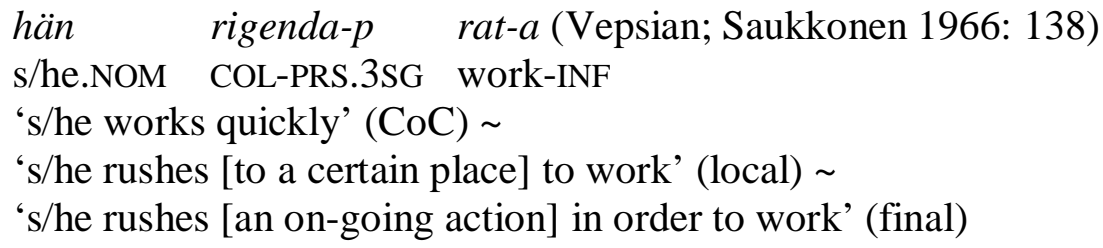

In general, the MA-infinitive illative (e.g., tulemaan) replaced the local function of the $*_{k}$-lative earlier than the A-infinitive translative (e.g., tullakseen) replaced the final function (see Table 5 in footnote 11). So in relative chronology, the A-infinitive translative is younger than the MA-infinitive illative as a morphological form (see Itkonen 1983: 363).

\subsubsection{Crystallization of the $\mathrm{CoC}$ and a note on syntax $\rightarrow$ pragmatics}

Figure 5 shows the end result of the grammaticalization process, namely, the current CoC. As described in the previous sections, phases in the grammaticalization cycle during syntax $\rightarrow$ morphology $\rightarrow$ morphophonemics ( $\rightarrow$ zero) represent mainly major structural changes in the Finnish infinitive and case system in general and the reanalysis process of the $\mathrm{CoC}$ in particular. The most important change has been $* k$-lative's gradual functional and structural fading (syn [case [ ] ]), which led to the semantic reorientation of the relationship between the A-infinitive and the colorative verb. This can be seen in the thick black line of the box, which represents the established constructional status of this verb syntagm. The two other structural changes are the extended word order variation from $\mathrm{COL}+\mathrm{INF}$ to INF $+\mathrm{COL}$ and the fact that there cannot be anything between the verbs in INF + COL variant; e.g., *mennä niin rauhallisesti körötteli, but körötteli niin rauhallisesti mennä 'COL-ed so calmly (to go)'. 
The later phase that the grammaticalization process went through after the reanalysis was extension by analogy. This has had its effects on the structural organization of the CoC by relaxing semantic constraints on both verb frames. The A-infinitive can basically be any verb whatsoever, not just a motion verb, and the colorative verb does not have to be only momentative. In fact, in my data there are even a few examples in which the colorative part of the $\mathrm{CoC}$ is not actually colorative in its lexical semantics as in example (16).
(16) navetta.tie-tä pitkin tul-lal loikk-i susi (DMA) cowhouse.path-PAR along come-INF leap-PRT.3SG wolf 'along the path to/from the cowhouse a wolf came leaping'

The verb loikkia ('to leap') in (16) is not particularly colorative, but it occupies the same structural position as true colorative verbs in the $\mathrm{CoC}$. The infinitive tulla ('to come') designates motion in general and deictic direction, while loikkia has a manner of motion meaning in its lexical semantics. In the CoC, a more or less neutral finite motion verb becomes "colored" as the whole construction emphasizes manner of action.

Figure 5. Colorative Construction

\begin{tabular}{|c|c|c|}
\hline syn [cat S] & \multicolumn{2}{|c|}{$\begin{array}{ll}\text { syn } & \text { [cat V] } \\
\text { sem } & \downarrow 1 \downarrow 2 \text { frame [MANNER-OF-ACTION] }\end{array}$} \\
\hline $\begin{array}{l}\operatorname{syn}\left[\begin{array}{ll}\text { cat } & \mathrm{NP} \\
\text { gf } & \text { subj }\end{array}\right] \\
\operatorname{sem} \operatorname{role}[\theta<\text { agt; theme }>] \\
1 x m \quad[\text { ] }\end{array}$ & $\begin{array}{l}\text { syn }\left[\begin{array}{cc}\text { cat } & \mathrm{V} \\
\text { fin } & - \\
\text { case } & {[}\end{array}\right] \\
\text { phon }-A^{\mathrm{x}} \\
\text { sem } \uparrow 2 \text { frame [ ] } \\
\text { lxm [ ] }\end{array}$ & $\begin{array}{l}\text { syn }\left[\begin{array}{cc}\text { cat } & \mathrm{V} \\
\text { fin } & + \\
\text { gf } & \text { head }\end{array}\right] \\
\text { phon [ ] } \\
\text { sem } \uparrow 1 \text { frame [COLORATIVE] } \\
\text { lxm [ ] }\end{array}$ \\
\hline
\end{tabular}

The semantic focusing of manner of action and structural orienting to a tight INF + COL word order variant led to a crystallized form of the $\mathrm{CoC}$ as described in Figure 5 (see Table 3). Even though the description of the grammaticalization of the $\mathrm{CoC}$ in this paper has not been usage-based in the sense of pragmatics, it has some corollaries on the pragmatic level. First, a clear semantic difference between the word order variants is 
hard to express, but in the INF + COL variant, the neutral A-infinitive verb categorizes the action in general, which is then modified semantically by the colorative verb. Thus, the A-infinitive names the explanatory frame for the descriptive colorative verb to modify. Precisely in that sense, the INF + COL order is pragmatically motivated: the A-infinitive offers interpretive background for the colorative verb. Second, the INF + COL order makes a structural distinction between the $\mathrm{CoC}$ and the other Finnish infinitive expressions and foregrounds its special character in that respect. Typically, in Finnish word order, the modifiers come after the finite verb. Third, the semantics of the CoC (MANNER-OF-ACTION) is more general than that of the proto-CoC (CHANGE-OF-STATE) or the pre-CoC (MANNER-OF-MOTION). In that respect, the CoC is pragmatically more usable than its historical predecessors, i.e., it can cover more states-of-affairs in the world than the previous versions of the construction.

\section{Summary and discussion}

In this paper, I have found it fruitful to take reconstructed proto-constructions as a starting point in trying to outline the gradual and episodic grammaticalization cycle of the Finnish CoC. Figure 6 gives a short recapitulation of the incremental process of the diachronic micro-steps (see Traugott \& Trousdale 2010: 20). As a grammatical construction, the $\mathrm{CoC}$ is lexeme-group specific, that is, it builds almost exclusively on onomatopoetic and descriptive colorative verbs in Finnish, and the A-infinitive serves as a sort of nametag explaining the overall action. The following summary is based directly on Figure 6.

First, the proto-CoC was a source structure for grammaticalization. In the Middle ProtoFinnic era, phrases such as *koira pyräšti joostak 'a dog abruptly started to run' (and similar correspondents in ex. 10) described sudden CHANGE-OF-STATE. The proto-CoC was quite a lenient verbal chain for two reasons: syntactically, there could be other words between the colorative and the A-infinitive, and semantically, the verbs designated distinct events. An iconic word order $\mathrm{COL}+\mathrm{INF}_{\mathrm{LAT}}$ sustained a sequential interpretation. Pragmatically, it was usable only for limited events, such as when someone or something was observed to begin moving abruptly. 
Figure 6. Summary for the grammaticalization of the $\mathrm{CoC}$

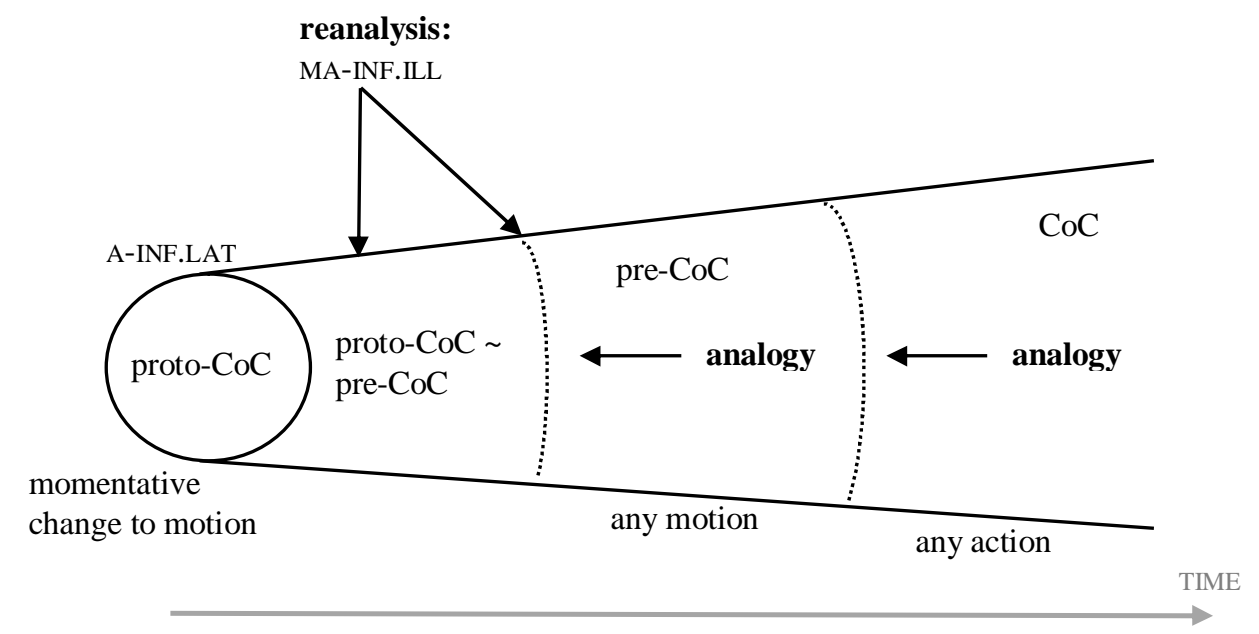

Second, the point at which grammaticalization set in goes back to the emerging coexistence of the $* k$-lative and the MA-infinitive illative respectively. The latter acted as an "external pushing force," gradually taking over the spatial function of the $* k$-lative, leading to the reanalysis of syntagmatic characteristics of the proto-CoC. The reanalysis itself, having structural surface markers or changes at the beginning (see e.g., Traugott \& Trousdale 2010: 33), led to an ambivalent situation in which both CHANGE-OF-STATE (the proto-CoC) and MANNER-OF-MOTION (the pre-CoC) interpretations were possible. Supposedly, these were pragmatically induced (Bybee 2010: 199). The pre-CoC reached MANNER interpretation due to the reanalysis; in effect, at this point, a new paradigmatic unit emerged. This essentially meant that the pre-CoC was compressed to semantically simultaneous verbal actions, as both verbs in the construction described the very same frame, type of motion (with the A-infinitive) plus manner of motion (with the colorative verb). 
Third, the MANNER-OF-MOTION interpretation enabled the colorative verb to be any motion verb. This set off a strong host class, which then acted as an analogical source for all the other action frames. The analogy likewise acted as an "internal pulling force," which absorbed new expressions from novel semantic domains. After the pre-CoC was established, analogy worked as a general mechanism to extend the usage of the CoC to non-motion frames as well. This can be seen as paradigmatic change. I find it likely that the purposive ("final") meaning of the $* k$-lative did not have any role in the grammaticalization of the CoC. Regardless of the accurate periods of analogical expansion, the result was a fresh grammatical construction whose semantic character was that of MANNER-OF-ACTION. Structurally, it consisted of a colorative finite verb with an infinitive. A strong tendency in favor of the fixed word order of INF + COL, particularly in Finnish, pinpointed its distinction from other infinitival expressions and motivated linearity in a new way: an infinitive designated an overall frame, and the colorative verb elaborated on it by depicting some special "colorative" aspects of manner of action.

There are two crucial aspects to point out from the perspective of grammaticalization. First, the process as a whole was gradual in the sense of being a series of micro-changes (Traugott \& Trousdale 2010: 23-26). Within the constructional framework, this was demonstrated by single feature changes (see Figures 2-5). Gradualness as such made sure that the grammaticalization process was non-reducible and inseparable from the coeffects of both reanalysis and analogy (Traugott \& Trousdale 2010: 38-39). Second, the genesis of the $\mathrm{CoC}$ is a prodigy for constructionalization; in other words, both the form and the meaning of a construction changed into another form and meaning. The gradual change can logically be formalized as follows (where $f=$ form and $m=$ meaning): $f_{1} / m_{1}$ $>\mathrm{f}_{1} \sim \mathrm{f}_{2} / \mathrm{m}_{1} \sim \mathrm{m}_{2}>\mathrm{f}_{2} / \mathrm{m}_{2}>\mathrm{f}_{\mathrm{n}} / \mathrm{m}_{\mathrm{n}}$. The reanalysis from the proto-CoC to the pre-CoC went through an ambiguous phase in which gradual structural change led to meaning change $\left(f_{1} / m_{1} \gg f_{2} / m_{2}\right)$, and then analogy spread the new expression to non-motion frames as well $\left(>f_{n} / m_{n}\right)$. The relative logical order of changes was reanalysis and then analogy, but the actual constructionalization process kept these tightly in tandem. 
Finally, in this paper I have given a detailed description of the constructionalization of the Finnish CoC. With the evidence from dialectal data and other closely related BaltoFinnic languages combined with $\mathrm{CxG}$ formalization, it is possible to give a plausible view of the gradual historical process involving reanalysis, semantic ambiguity, and analogy. This strengthens the pivotal idea of constructionalization as one type of grammatical change in general. However, it remains for future empirical research to solve such problems as the possible cross-constructionality and micro-constructional variation between Balto-Finnic languages and perhaps other genetically related FinnoUgric languages more generally. Moreover, potential universal aspects of ideophonic expressions await a thorough typological study. The lexicalization of ideophones, coverbs, converbs, and serial verb constructions offers an important line of inquiry for these kinds of studies. 


\section{Abbreviations and symbols}

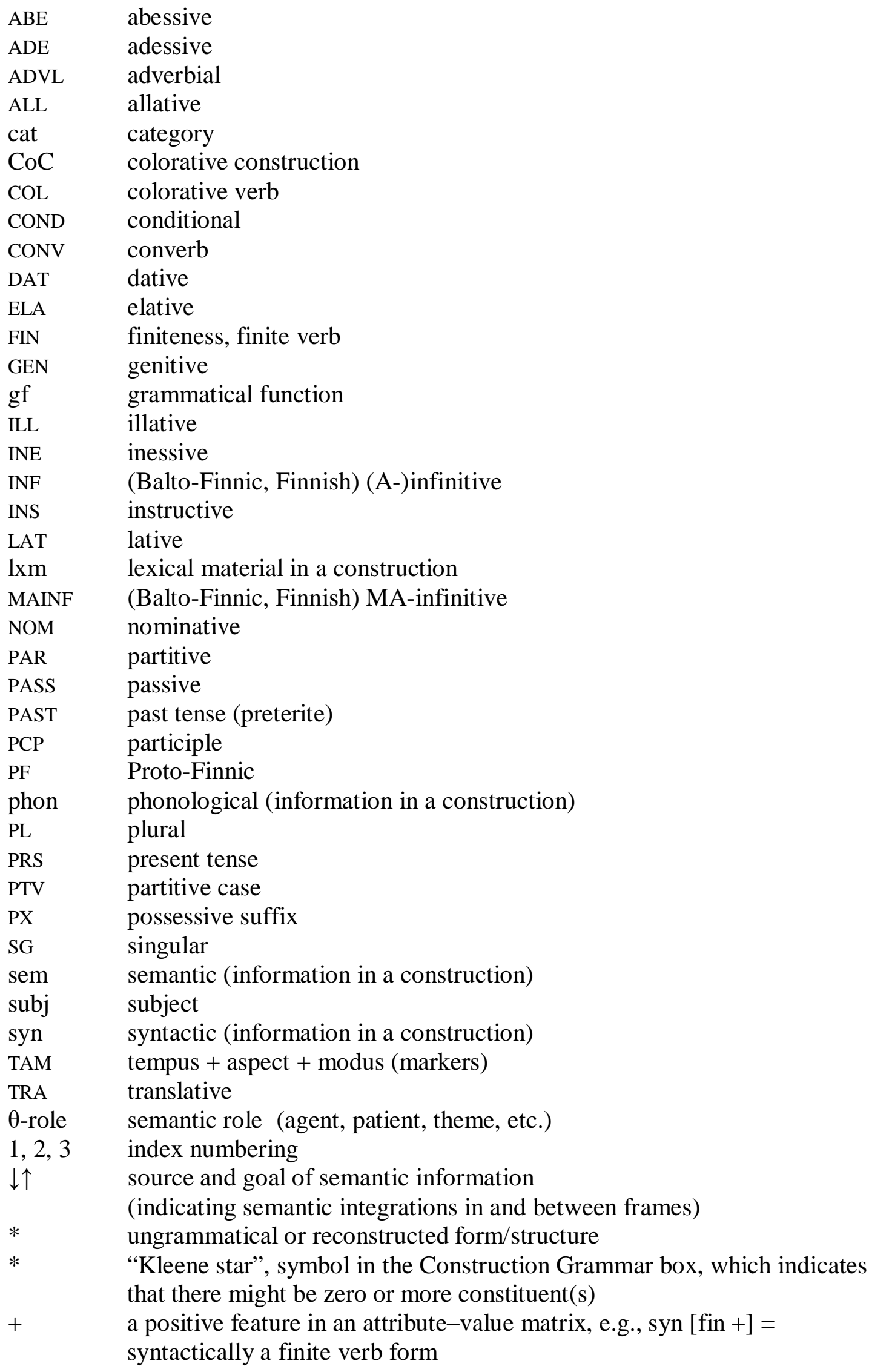




a negative feature in an attribute-value matrix, e.g., syn [fin -] =
syntactically a non-finite verb form
morpheme boundary

\section{Data archives}

DMA = Digitaalinen muoto-opin arkisto (Digital Morphology Archive). Collected by the Morphology Archive of the Department of Finnish, Finno-Ugrian, and Scandinavian Studies at the University of Helsinki and the CSC - IT Center for Science. Accessed 12 June 2016. Available at https://korp.csc.fi

KKSK $=$ Karjalan kielen sanakirja (Dictionary of Karelian). Online database for the list of lexical entries. Helsinki: Institute for the Languages of Finland. Accessed 12 June 2016. Updated periodically. Available at http://kaino.kotus.fi/sanat/kkss/

LA = Lauseopin arkisto (Syntax Archives). Institute for the Languages of Finland and the School of Language and Translation Studies at the University of Turku. Turku: Syntax Archives. Accessed 12 June 2016. Available at https://korp.csc.fi

SMS = Suomen murteiden sanakirja (Dictionary of Finnish Dialects), vols. 1-8. Helsinki: Institute for the Languages of Finland. Accessed 12 Jun 2016. Available at http://kaino.kotus.fi/sms/

\section{References}

Anttila, Raimo (1973). Internal Reconstruction and Finno-Ugric (Finnish). In Thomas A. Sebeok (Ed.), Current trends in linguistics. Vol. 11: Diachronic, areal and typological linguistics (317-353). The Hague: Mouton.

(1977). Toward a Semiotic Analysis of Expressive Vocabulary. Semiosis 5, Internationale Zeitschrift für Semiotik und ihre Anwendungen, Heft 1, 27-40.

Barlow, Michael \& Suzanne Kemmer (Eds.) (2000). Usage-based Models of Language. CSLI Publications. Stanford, California: Center for the Study of Language and Information.

Bergs, Alexander \& Gabriele Diewald (Eds.) (2008). Constructions and Language Change. Trends in Linguistics. Studies and Monographs 194. Berlin: Mouton de Gruyter.

Bergsland, Knut (1994). Sydsamisk grammatikk [South Sami Grammar]. Second edition. Karasjok: Davvi girji.

Boas, Hans \& Mirjam Fried (Eds.) (2006). Grammatical Constructions: Back to the roots. Constructional Approaches to Language 4. Amsterdam \& Philadelphia: John Benjamins Publishing Company. 
Bybee, Joan (2010). Language, Usage and Cognition. Cambridge: Cambridge University Press.

Closs Traugott, Elizabeth (2008a). Grammatikalisierung, emergente Konstruktionen und der Begriff der "Neuheit". In Kerstin Fischer \& Anatol Stefanowitsch (Eds.), Konstruktionsgrammatik: Von der Konstruktion zur Grammatik (5-32). Stauffenburg Linguistik Band 47. Germany: Stauffenburg Verlag.

(2008b). Constructions in Grammaticalization. In Brian D. Joseph \& Richard D. Janda (Eds.), The Handbook of Historical Linguistics (624-647). 3rd Edition. Oxford: Blackwell Publishing.

Closs Traugott, Elizabeth \& Bernd Heine (Eds.) (1991). Approaches to grammaticalization. Volume 1. Focus on theoretical and methodological issues. Amsterdam: John Benjamins Publishing Company.

Closs Traugott, Elizabeth \& Graeme Trousdale (2014). Constructionalization and Constructional Changes. Oxford: Oxford University Press.

(2010). Gradience, gradualness and grammaticalization. How do they intersect? In Elizabeth Closs Traugott \& Graeme Trousdale (Eds.), Gradience, Gradualness and Grammaticalization (19-44). Typological Studies in Language 90. Amsterdam: John Benjamins Publishing Company.

Diewald, Gabriele (2007). Konstruktionen in der diachronen Sprachwissenschaft. In Kerstin Fischer \& Anatol Stefanowitsch (Eds.), Konstruktionsgrammatik: Von der Anwendung zur Theorie (79-103). Updated $2^{\text {nd }}$ edition, Stauffenburg Linguistik Band 40. Germany: Stauffenburg Verlag.

Erhard Voeltz, F. K. \& Christa Kilian-Hatz (2001). Introduction. In F. K. Erhard Voeltz \& Christa Kilian-Hatz (Eds.), Ideophones (1-8). Typological Studies in Language 44. Amsterdam \& Philadelphia: John Benjamins Publishing Company.

Fillmore, Charles \& Paul Kay (1995). Construction Grammar. CSLI Lecture Notes. Stanford, California: Center for the Study of Language and Information.

Fried, Mirjam (2009). Construction Grammar as a tool for diachronic analysis. Constructions and Frames, 1(2), 262-291.

Fried, Mirjam \& Jan-Ola Östman (2004). Construction Grammar. A Thumbnail sketch. In Mirjam Fried \& Jan-Ola Östman (Eds.), Construction Grammar in a CrossLanguage Perspective (11-86). Constructional Approaches to Language 2. Amsterdam: John Benjamins Publishing Company.

Givón, Talmy (1979). On Understanding Grammar. New York: Academic Press Inc.

Goldberg, Adele E. (1995). Constructions: A Construction Grammar Approach to Argument Structure. Chicago \& London: The University of Chicago Press. (2006). Constructions at work: The Nature of Generalization in Language. Oxford: Oxford University Press. 
Haiman, John 1980: The Iconicity of Grammar: Isomorphism and Motivation. Language 56(3): 515-540.

Hakulinen, Lauri (1961). The Structure and Development of the Finnish Language. Indiana University publications, Uralic and Altaic Series, Vol. 3. Translated by John Atkinson. Bloomington, IN: Indiana University Press.

Haspelmath, Martin (2010). Comparative concepts and descriptive categories in crosslinguistic studies. Language, 86(3), 663-687.

Heikkilä, Mikko K. (2014). Bidrag till Fennoskandiens språkliga förhistoria i tid och rum [dissertation]. Helsinki: Helsingfors universitet.

Heikkinen, Vesa \& Eero Voutilainen (2009). Koloratiivirakenne Hirventappopaikkaromaanissa [The Colorative Construction in the novel Hirventappopaikka]. In Vesa Heikkinen (Ed.), Kielen piirteet ja tekstilajit: Vaikuttavia valintoja tekstistä toiseen [Features and genres of the language: Expressive choices from a text to another] (135169). Tietolipas 229. Helsinki: Suomalaisen Kirjallisuuden Seura.

Heine, Bernd, Ulrike Claudi \& Friedrike Hünnemeyer (1991). Grammaticalization: A conceptual framework. Chicago: The University of Chicago Press.

Herlin, Ilona, Pentti Leino \& Laura Visapää (2005). Kas siinä pulma [That is the question]. In Ilona Herlin \& Laura Visapää (Eds.), Elävä kielioppi: Suomen infiniittisten rakenteiden dynamiikkaa [Living grammar: Dynamicity of Finnish infinitival structures] (9-38). Suomalaisen Kirjallisuuden Seuran Toimituksia 1021. Helsinki: Suomalaisen Kirjallisuuden Seura.

Himmelmann, Nikolaus P. (2004). Lexicalization and grammaticalization: Opposite or orthogonal? In Walter Bisang, Nikolaus P. Himmelmann \& Björn Wiemer (Eds.), What makes grammaticalization: a look from its fringes and its components (21-42). Trends in linguistics. Studies and monographs 158. Berlin: Mouton de Gruyter.

Hopper, Paul J. \& Elizabeth Closs Traugott (2003). Grammaticalization. Cambridge Textbooks in Linguistics, second edition. Cambridge: Cambridge University Press.

Ikola, Osmo, Ulla Palomäki \& Anna-Kaisa Koitto (1989). Suomen murteiden lauseoppia ja tekstikielioppia [Syntax and text linguistics of Finnish dialects]. Suomalaisen Kirjallisuuden Seuran Toimituksia 511. Helsinki: Suomalaisen Kirjallisuuden Seura.

Itkonen, Terho (1964). Proto-Finnic Final Consonants: Their History in the Finnic Languages with Particular Reference to the Finnish Dialects I: 1. Introduction: The History of -k in Finnish. Helsinki: Suomalaisen Kirjallisuuden Seura.

(1983). Välikatsaus suomen kielen juuriin [Retrospective view to the roots of Finnish]. - Virittäjä 87: 349-386. 
Jarva, Vesa \& Samu Kytölä (2007). The Finnish Colorative Construction and Expressivity. SKY Journal of Linguistics, 20, 235-272.

Jomppanen, Marjatta (2011). Pohjoissaamen ja suomen kielen koloratiivikonstruktio vertailussa [Comparison of colorative constructions in Finnish and North Saami]. In Annekatrin Kaivapalu, Johanna Laakso, Pirkko Muikku-Werner \& Maria-Maren Sepper (Eds.), Lähivõrdlusi/Lähivertailuja 21 (106-131). Tallinn: Eesti Rakenduslingvistika Ühing. Available at http://www.rakenduslingvistika.ee/ul/files/LV2105Jomppanen.pdf [Accessed 28 Sep. 2016].

Karelson, Rudolf (1959). Soome-ugri keelte lausestruktuurist seoses konjunktsioonidega [Finno-Ugric clause structure with conjunctions]. Eesti Seltsi Aastaraamat IV, 195-213.

Karlsson, Fred (1999). Finnish: an essential grammar. New York: Taylor \& Francis eLibrary.

Kettunen, Lauri (1943). Vepsän murteiden lauseopillinen tutkimus [Syntactic research on Veps dialect]. Suomalais-Ugrilaisen Seuran Toimituksia LXXXVI. Helsinki: Suomalais-Ugrilainen Seura.

Kim, Jong-Bok (2012). The English Binominal NP Construction: A Construction Grammar Approach. Plenary presentation in $7^{\text {th }}$ International Conference on Construction Grammar in Seoul, Korea.

Korhonen, Mikko (1981). Johdatus lapin kielen historiaan [An introduction to the history of Saami language] Suomalaisen Kirjallisuuden Seuran Toimituksia 370. Helsinki: Suomalais-Ugrilainen Seura.

Langacker, Ronald W. (1987). Foundations of Cognitive Grammar. Volume I: Theoretical Prerequisites. Stanford: Stanford University Press. (2010). Grammar and Conceptualization. Cognitive Linguistic Research 14. Berlin: Mouton de Gruyter.

Leino, Jaakko (2005). Frames, profiles and constructions: Two collaborating CGs meet the Finnish Permissive Construction. In Jan-Ola Östman \& Mirjam Fried (Eds.), Construction Grammars: Cognitive grounding and theoretical extensions (89-120). Constructional Approaches to Language 3. Amsterdam \& Philadelphia: John Benjamins Publishing Company.

Lehmann, Christian ([1982] 2002). Thoughts on Grammaticalization. Arbeitspapiere des Seminars für Sprachwissenschaft der Universität Erfurt, Nr. 9. Second, revised edition. Erfurt: Seminar für Sprachwissenschaft, Philosophische Fakultät, Universität.

Lehtinen, Tapani (2007). Kielen vuosituhannet. Suomen kielen kehitys kantauralista varhaissuomeen [Millenia of the language. Evolution of Finnish language from ProtoUralic to early literal Finnish] Tietolipas 215. Helsinki: Suomalaisen Kirjallisuuden Seura. 
Mihkla, K. (1964). Öeldis [Predicate]. In K. Mihkla (Ed.), Eesti keele süntaks I: prooviartikleid lihtlause süntaksi alalt [Syntax of Estonian I: research articles on the syntax of simple sentences] (66-101). Tallinn: Eesti NSV Teaduste Akadeemia Keele ja Kirjanduse Instituut.

Mikone, Eve 2001: Ideophones in the Balto-Finnic languages. In F. K. Erhard Voeltz \& Christa Kilian-Hatz (Eds.), Ideophones (224-233). Typological Studies in Language 44. Amsterdam \& Philadelphia: John Benjamins Publishing Company.

Nickel, Klaus Peter (1994). Samisk grammatikk [Sami Grammar]. Second, revised edition. Karasjok: Davvi Girji O. S.

Nielsen, Konrad ([1926]1979). Laerebok i lappisk (samisk) I Grammatikk [Schoolbook on Sami I Grammar]. Second edition. Oslo: Universitetsforlaget.

Noël, Dirk (2007). Diachronic construction grammar and grammaticalization theory. Functions of Language, 14 (2), 177-202.

Posti, Lauri (1980). Vatjan kielen Kukkosin murteen sanakirja [The dictionary of Votic dialect of Kukkos]. Lexica Societatis Fenno-Ugricae XIX. Helsinki: SuomalaisUgrilainen Seura.

Põlma, Valve (1967). Onomapoeetilised verbid eesti kirjakeeles [Onomatopoetic verbs in Estonian literary language]. Tallinn: Eesti NSV Teaduste Akadeemia Keele ja Kirjanduse Instituut.

Ringe, Don (2008). Internal Reconstruction. In Brian D. Joseph \& Richard D. Janda (Eds.), The Handbook of Historical Linguistics (244-261). Third Edition. Oxford: Blackwell Publishing.

Rostila, Jouni (2004). Lexicalization as a way to grammaticalization. In Fred Karlsson (Ed.) Proceedings of the $20^{\text {th }}$ Scandinavian Conference of Linguistics. Available at http://www.ling.helsinki.fi/kielitiede/20scl/Rostila.pdf [Accessed 14 Oct. 2016]. (2006). Storage as a way to grammaticalization. Constructions

1/2006. Available at www.constructions-online.de [Accessed 17 Apr. 2016].

Rytkönen, Ahti (1937). Koloratiivinen konstruktio [The colorative construction]. Virittäjä, 41, 95-104.

Saukkonen, Pauli (1965). Itämerensuomalaisten kielten tulosijainfinitiivirakenteiden historiaa I: johdanto: adverbiaali infinitiivi [The history of Balto-Finnic lative infinitival constructions I: introduction: adverbial infinitive]. Suomalais-Ugrilaisen Seuran Toimituksia 137. Helsinki: Suomalais-Ugrilainen Seura. (1966). Itämerensuomalaisten kielten tulosijainfinitivivirakenteiden historiaa II: adverbaali infinitiivi (täydennys), adnominaali infinitiivi, absoluutti infinitiivi, elliptinen infinitiivi [The history of Balto-Finnic lative infinitival constructions II: adverbial 
infinitive (supplement), adnominal infinitive, absolute infinitivi, elliptic infinitive]. Suomalais-Ugrilaisen Seuran Toimituksia 140. Helsinki: Suomalais-Ugrilainen Seura.

Setälä, Eemil Nestor (1880). Suomen kielen lauseoppi: Oppikirjan koe [Finnish syntax: A trial for a schoolbook]. Helsinki: K. E. Holm.

Virtaranta, Pertti (1986). Haljärven lyydiläismurteiden muoto-oppia [Morphology of Ludic dialects in Haljärvi] Suomalais-Ugrilaisen Seuran Toimituksia 190. Helsinki: Suomalais-Ugrilainen Seura.

ISK = Auli Hakulinen, Maria Vilkuna, Riitta Korhonen, Vesa Koivisto, Tarja Riitta Heinonen ja Irja Alho (2004). Iso suomen kielioppi [The large Finnish grammar]. Helsinki: Suomalaisen Kirjallisuuden Seura. Available at http://scripta.kotus.fi/visk [Accessed 18 Jan. 2016].

Ylikoski, Jussi (2011). A survey of the origins of directional case suffixes in European Uralic. In Seppo Kittilä, Katja Västi \& Jussi Ylikoski (Eds.), Case, Animacy and Semantic Roles (235-280). Amsterdam \& Philadelphia: John Benjamins Publishing Company.

(2003). Defining Non-finites: Action Nominals, Converbs and Infinitives. SKY Journal of Linguistics, 16, 185-237. 


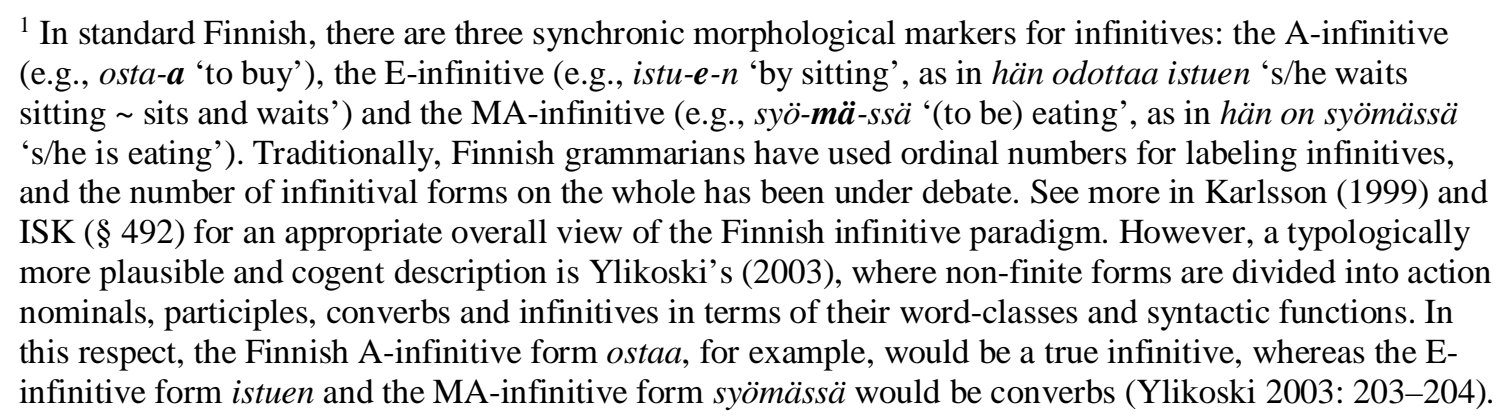

${ }^{2}$ Examples $(4 a-c)$ are all fabricated in standard Finnish, but they are strongly based on the SMS corpus; s. v. ahkuta.

${ }^{3}$ I would like to thank Jussi Ylikoski, Mikko Heikkilä, and two anonymous reviewers for their valuable comments and attentions.

${ }^{4}$ The LA corpus is syntactically and morphologically coded, but the CoCs have to be manually separated from other syntactic structures that include an A-infinitive as an adverbial. The corpus is based on the XML database, which operates with xpath expressions. All the CoCs from this corpus have been separated from the raw data (338 hits) based on the following xpath command:

XPath: //cl[w[contains(@mrp, 'inf1') and @ fun='advl:v']]/ancestor-or-self::s.

The LA consists of two subcorpora: a dialect corpus (spoken language) and a corpus of standard Finnish (written texts); only the first has been used here.

${ }^{5}$ There are 408 manually gathered examples of the $\mathrm{CoC}$ from the DMA corpus. The total number of Ainfinitive expressions amounted to 15,192 instances (at the search moment). In the DMA, CoCs can be found under the signum 740 (= active 1. infinitive lative forms).

${ }^{6}$ Because the SMS is built on a Filemaker-database, it accepts only simple and cumbersome regular expressions for data gathering. Thus, several ways have to be used to search, and even then the result will not be exhaustive. The search expression <koloratiivi.*> was used for the CoCs in volumes 1-8 of the SMS. With this method, 220 lexical entries were found, and 1,249 examples were manually separated from these entries. Basically, this means that 220 lexemes (in volumes 1-8) have the following definition: "[the word/verb used] usually in Colorative Constructions." In general, the SMS is suitable enough for current purposes, particularly because it usually gives important semantic explanations for otherwise uncommon colorative verbs, and it also reports geographical information.

${ }^{7}$ Jarva and Kytölä (2007: 269) have glossed the verb form menisin 'I would go' as past tense, even though, morphologically, it is present tense (PRS). In this particular context, however, menisin might be interpreted temporally as past, because the finite verb is in the past tense. Nevertheless, morphologically, conditionals are considered not to have simple past tense forms in Finnish, but only present (menisin) and perfect forms (olisin mennyt 'I would have gone'). Jarva and Kytölä refer to their own examples (11) and (6), which are as follows: (ex. 11, on p. 245) minä tahdoin mennä sen ojan ylitse 'I wanted to go across that ditch' and (ex. 6, on p. 242) susi lotkotti mennä erellä (LA) 'the wolf went-COL ahead'.

${ }^{8}$ Structural assimilation rules are as follows: ${ }^{\mathrm{x}} \rightarrow \mathrm{C}_{\mathrm{i}} /$ _ $\# \mathrm{C}_{\mathrm{i}}$ (as in ex. 9a) and ${ }^{\mathrm{x}} \rightarrow$ ? / _ \# ${ }^{\text {? }} \mathrm{V}$ (as in ex. $9 b)$. At the very end, $x$ does not occur at all. Even clitic suffixes (e.g., [nousta:kin] nousta 'to rise' + kin 'also') and composed words (e.g., [herne:keitto] herne 'pea' + keitto 'soup', 'peasoup') trigger the assimilation. In Finnish language studies this phenomenon is called rajageminaatio ("juncture gemination"), loppukahdennus ("end duplication"), and alkukahdennus ("initial duplication"), among other designations. In fact, there are several specific morphological forms in current spoken Finnish, both nominal (i.e., allative case, 3. person possessive suffix, certain nouns ending in -e) and verbal (i.e., Ainfinitive, 2. person singular imperative, negative present forms), which are related to this assimilation phenomenon. There is a relatively well-acknowledged consensus on the phenomenon's historical origins, but synchronically, it is not always clear what kind of feature it actually is. In the glosses (ex. 9a-b), the $\mathrm{x}$-feature is attached with brackets to the A-infinitive morpheme specifically to indicate that it is a 
morpheme-based relic. As the synchronic issue is not relevant from a historical point of view, I will not deal further with it here.

${ }^{9}$ It is crucial to note that examples $(10 \mathrm{a}-\mathrm{c})$ do not necessarily represent accurately any definite protolinguistic stage, but rather merely demonstrate the characteristics that the proto-CoC probably had. In this paper, the same principle applies to all the reconstructions addressed in the text.

${ }^{10}$ Early Proto-Finnic is considered to be the diachronic stage when the (Proto-)Sami and Balto-Finnic languages were not yet disengaged (ca. 1500-1000 BCE). Late Proto-Finnic, in turn, represents the historical stage during which the Balto-Finnic languages gradually evolved into individual daughter languages (ca. 1000-0 BCE), breaking off the historical links with Sami. (See, e.g., Korhonen 1981: 27; Ylikoski 2011: 237-239; Heikkilä 2014.)

${ }^{11}$ As can be seen in Table 4, the process of restructuring continued, and new non-finite forms appeared during the historical development of Finnish as an individual language. The MA form in particular acquired new case markers, and current non-finites became somewhat idiosyncratic in their paradigms and even partly dependent on a dialect in certain constructions. Moreover, some non-finite forms are already periphrastic or construction-specific, such as the - $m A s s A$ form (the MA form's inessive) used in a progressive meaning with the verb olla 'to be, exist'; e.g., hän on juoksemassa 's/he is running'. As for the current research, there is neither reason nor space to investigate different (synchronic) infinitive constructions further, and even less for considering the historical development of these constructions. Research on the latter topic is also very scarce (however, see Leino 2005: 89-120).

Table 5. The morphological paradigm of (active) non-finite forms (except participles) in Finnish from Early Proto-Finnic to modern Finnish (see Lehtinen 2007; Ylikoski 2003).

\begin{tabular}{|c|c|c|c|c|c|c|}
\hline Early Proto-Finnic (PF) & \multicolumn{3}{|c|}{ Late Proto-Finnic (LPF) } & \multicolumn{3}{|c|}{ (modern) Finnish } \\
\hline \multirow[t]{2}{*}{ *tuleta-k come-LAT/TRA } & $\begin{array}{l}\text { INF } \\
\text { CONV }\end{array}$ & $\begin{array}{l}\text { *tulða-(k) } \\
\text { *tulðak-kse(+PX) }\end{array}$ & $\begin{array}{l}\text { come- } \varnothing \\
\text { come-TRA }\end{array}$ & $\begin{array}{l}\text { INF } \\
\text { CONV }\end{array}$ & $\begin{array}{l}\text { tulla } \\
\text { tullakse(+PX) }\end{array}$ & $\begin{array}{l}\text { come- } \varnothing \\
\text { come-TRA }\end{array}$ \\
\hline & $\begin{array}{l}\mathrm{CONV} \\
\mathrm{CONV}\end{array}$ & $\begin{array}{l}\text { *tulðe-ssa(+PX) } \\
\text { *tulðe-n }\end{array}$ & $\begin{array}{l}\text { come-INE } \\
\text { come-INS }\end{array}$ & $\begin{array}{l}\text { CONV } \\
\text { CONV }\end{array}$ & $\begin{array}{l}\text { tullessa }(+\mathrm{PX}) \\
\text { tullen }\end{array}$ & $\begin{array}{l}\text { come-INE } \\
\text { come-INS }\end{array}$ \\
\hline $\begin{array}{r}* \text { tulema-na come- INE/ } \\
\text { general locative }\end{array}$ & $\begin{array}{l}\text { INF } \\
\text { INF } \\
\text { INF }\end{array}$ & $\begin{array}{l}\text { *tulema-ssa } \\
\text { *tulema-sta } \\
\text { *tulema-sen }\end{array}$ & $\begin{array}{l}\text { come-INE } \\
\text { come-ELA } \\
\text { come-ILL }\end{array}$ & $\begin{array}{l}\text { INF } \\
\text { INF } \\
\text { INF } \\
\text { CONV } \\
\text { CONV } \\
\text { (INF }\end{array}$ & $\begin{array}{l}\text { tulemassa } \\
\text { tulemasta } \\
\text { tulemaan } \\
\text { tulema-lla } \\
\text { tulema-tta } \\
\text { tulema-n }\end{array}$ & $\begin{array}{l}\text { come-INE } \\
\text { come-ELA } \\
\text { come-ILL } \\
\text { come-ADE } \\
\text { come-ABE } \\
\text { come-INS) }\end{array}$ \\
\hline
\end{tabular}

${ }^{12}$ Internal local cases in the MA-infinitive are prototypical in spatial use: hän meni uima-an 's/he went to swim' (ILL), hän oli uima-ssa 's/he was swimming' (INE), hän tuli uima-sta 's/he came from swimming' (ELA). There is a clear semantic symmetry. By comparison, there is just one form in the MA-infinitive external case that does not have a spatial, locative meaning, but rather an instrumental meaning: hän meni uima-lla saareen 's/he went to the island by swimming' (ADE).

${ }^{13}$ In Estonian, the infinitive forms are similar to those in Finnish, i.e., A-, E- and MA-infinitives, but the case distribution differs slightly. The illative cannot be attached to the MA-infinitive form, even though in example (10c), seisma is functionally equivalent to Finnish seisomaan in the parallel example hän ponnahtaa seisomaan 's/he stands up quickly'. I would like to express my gratitude to Peeter Teenets for having clarified some of the Estonian infinitive usages. 